\title{
THE ZOOPLANKTON OF THE RÁCKEVE-SOROKSÁR DANUBE: SPATIO-TEMPORAL CHANGES AND SIMILARITY PATTERNS
}

\author{
CS. VADADI-FÜLÖP ${ }^{1, *}-$ G. MÉSZÁROS ${ }^{2}-$ GY. JABLONSZKY ${ }^{1}-$ L. HUFNAGEL $^{3 *}$ \\ ${ }^{I}$ Eötvös Loránd University \\ H-1117 Budapest, Pázmány P. sétány 1/c, Hungary \\ ${ }^{2}$ Szent István University \\ H-2100 Gödöllö, Páter K. út. 1., Hungary \\ ${ }^{3}$ „Adaptation to Climate Change” Research Group of Hungarian Academy of Sciences \\ H-1118 Budapest, Villányi út 29-43., Hungary \\ (phone: +36-1-482-6261; fax: +36-1-466-9273) \\ *Corresponding author \\ e-mail:vadfulcsab@gmail.com \& leventehufnagel@gmail.com \\ (Received $4^{\text {th }}$ March 2008 ; accepted 12nd august 2008)
}

\begin{abstract}
The Ráckeve-Soroksár Danube has a great importance as it is the second largest side arm in the Hungarian section of the river Danube and many demands of exploitation are expected. The aim of this study is to analyse the spatial and temporal changes of the zooplankton (Copepoda, Cladocera) community in this river arm, moreover the similarity patterns of zooplankton communities in different Hungarian water bodies are presented in special consideration of the Ráckeve-Soroksár Danube. Basically this study is based on data from literature, however our data are also used for compiling the database for the spatio-temporal changes of the Ráckeve-Soroksár Danube. We put emphasis on the three typical sections of the side arm, as these are stressed due to hydromorphological aspects, but creating artificial borders are objectionable as well. The results show that both spatial and temporal changes are evident, what is more, the stagnant water character of the side arm should be underlined.
\end{abstract}

Keywords. Copepoda, Cladocera, fauna, composition

\section{Introduction}

The Ráckeve-Soroksár Danube (hereafter abbreviated as RSD) is the second largest side arm in the Hungarian section of the river Danube, and is located between the 1642 and 1586 river kilometres. Geographically it is located on the Csepeli-sík, mostly south of Budapest, besides in north at Pesterzsébet, Soroksár and Dunaharaszti smaller segment of the arm assorts with the Pesti hordalékkúp-síkság (alluvium plain of Pest). RSD's area is a temperately warm, dry climated small-scene [28]. The river arm is 58 $\mathrm{km}$ long from which $11 \mathrm{~km}$ belongs to the area of Budapest. It is enclosed by the two estaurine works Kvassay- and Tass sluices, therefore water level is manageable. The current velocity is very low, $0,1-0,3 \mathrm{~m} / \mathrm{s}$. The shoreline is $120 \mathrm{~km}$ long, the shoreline length of the islands and side arms is $60 \mathrm{~km}$, so the whole shoreline is altogether 180 $\mathrm{km}$ long, which is equal to that of lake Balaton [25]. The water level fluctuation is between $20-60 \mathrm{~cm}$, the decline of water is between $10-30 \mathrm{~cm}$. The catchment area is around $1800 \mathrm{~km}^{2}$. Important waters connecting to the RSD are the Danube-Tisza canal, I. Árapasztó canal, Kiskunsági canal, Gyáli creek.

The Danube arm (Fig 1.) could be devided into three typical sections. The upper section (38-58 rkm) alters most dinamically that is caused by the large amounts of mud. Body of water is 4,5-6 million $\mathrm{m}^{3}$, the river bed is shallow (2-3 m) and narrow (80-200 
$\mathrm{m}$ ), that is why the highest current velocity could be observed here. However this velocity is substantially lower as compared with the Danube, which has several effects. Primarily the floating matter settles here transported from the Danube and pollution is intense. The inadequate quality of water derived from the main arm has the severest effect here. In addition several sources of pollution coming from industrial establishments make the water quality even worse. Three islands are situated here: Molnár-, Czuczor- , and Dunaharaszti-Taksony-island, but their island-like character is hardly dominant because of the large amounts of mud. Next section (22-38 rkm) is deeper and wider (average bed width 350-400 m, water depth 2,5-3 m), body of water is 16-18 million ${ }^{3}$. Extended reeds are characteristic of this stretch that extends between Szigethalom and Ráckeve. This section is of great importance in respect of spawning. In addition the unique floating bogs can be seen here. The lower section $(0-22 \mathrm{rkm})$, located between Ráckeve and Tass sluice, has a bed width of $300 \mathrm{~m}$, and water depth of 3,5-6 m. Body of water is 20-25 million $\mathrm{m}^{3}$ that adds up to 50-55 \% of the whole water body of the RSD. Reeds can be found only in the narrow shore zone. Current velocity is very low, it can be regarded as a stagnant water. Water quality is most favourable here, mostly suitable for fishing. This triple division must be kept in our mind as the spatial changes of the zooplankton community are based mainly on this phenomenon.

The three sections of the RSD show considerably distinct faces studying the anthroponetic environment of them. This feature is followed after the location of the river arm e.g. the three segments lie in a continuous, however geographically diversified milieu. This type of diversity is sensible both in physical and regional geographical points of view. Physical geographical aspects have already shown before [46]. Studying regional geograhical aspects a few essential parameters are necessary to be mentioned.

Approximately the half long of the upper section (situated between 38 and $58 \mathrm{rkm}$ ) belongs to the administrative area of the capital city of Budapest. This section is located in the mostly built-up area along the RSD comprising both industrial and residential zones, which esentially determinates certain ecological features. Especially from the $90 \mathrm{~s}$ the residential function has started to escalate in this area while the significance of the industry has been reduced. Population density achieves the highest level along this section in the whole RSD.

The next section (22-38 rkm) is located in a transitional zone in regional geographical aspect. The town of Szigethalom existing in the northern edge of this segment belongs to the administrative conurbation existing round Budapest (together with Majosháza, which lies on the other side of the RSD, approximately $10 \mathrm{~km}$ to the southern direction). By this time Szigethalom was built together with the suburban town Szigetszentmiklós existing on the riverbank, accordingly the western side of the RSD has became fully built up around the mentioned area. Although other extensive built up riverbank areas are present around Szigetcsép, Majosháza and Szigetszentmárton, generally the lower part of this segment is traditionally unbuilt, despite a nearly continual immediate built-up strip along the RSD itself. Accordingly the population density is much lower in this segment than in the upper section shown before.

The largest settlement around the lower section of the arm (situated between 0 and $22 \mathrm{rkm})$ is Ráckeve, which lies directly adjacent to the RSD. Traditionally it was situated on Csepel Island, nevertheless it has already started to expand on the other bank of the arm as well. Also a notable settlement is Dömsöd located on the eastern side of the RSD, besides the mentioned narrow strip along the arm, mostly built up with 
holiday houses. Population density is relatively low and the character of the sorroundings is defined by the growing distance from the capital.

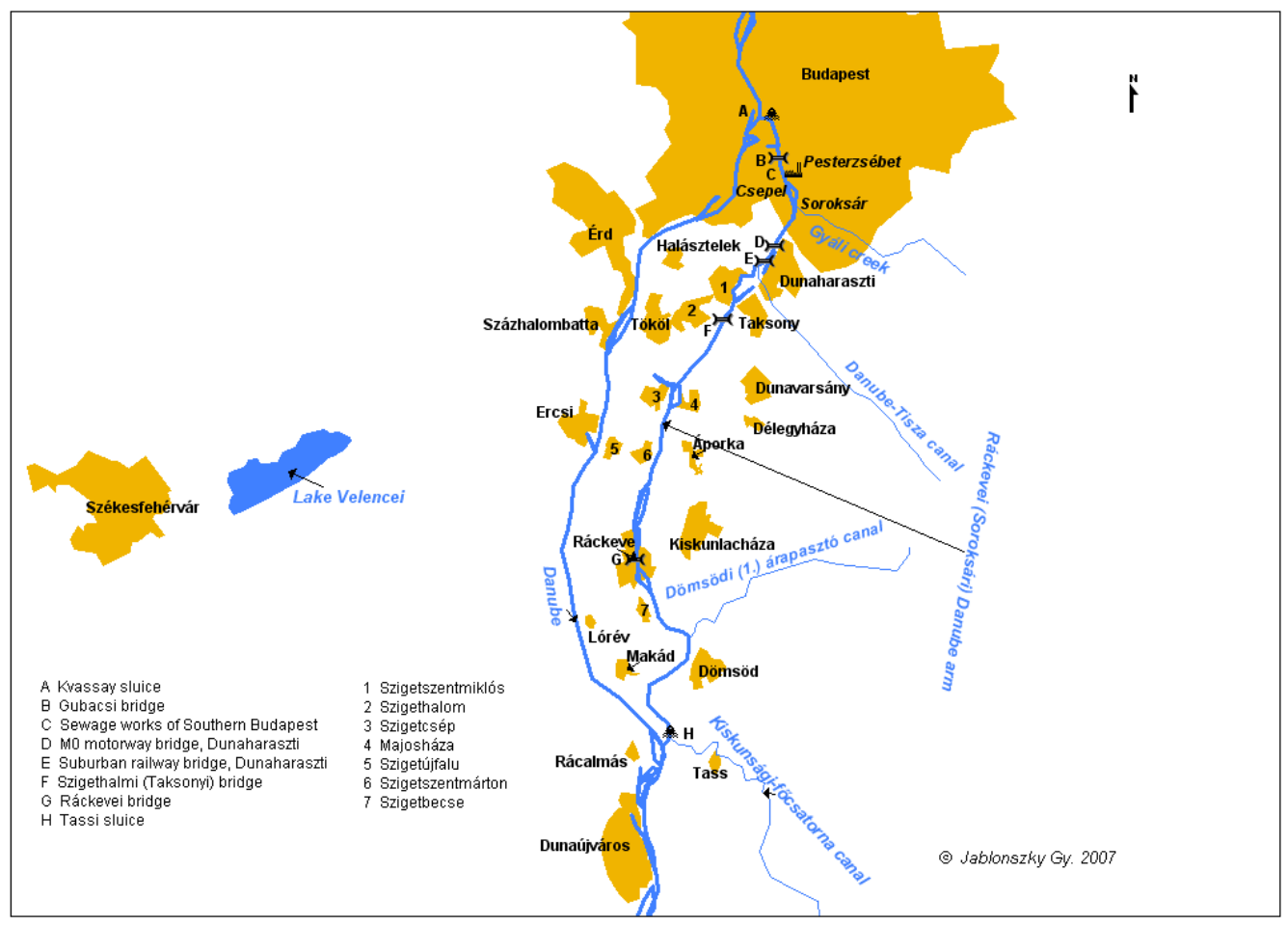

Figure 1. Map of the RSD with sampling sites, settlements and important works.

The RSD is of great importance in the aspects of watering, industrial water usage, diversion of inland waters, water for fishponds, recreation, aquatic sports, fishing and the close position to the capital. Therefore the better understanding of the biota living here is crucial, including biological processes as well. Zooplankton is considered an important compartment of aquatic ecosystems for its role in the trophic chain. It represents the channel of transmission of the energy flux from the primary producers to the top consumers [1]. Hence it is of great interest to study planktonic Crustacea, including spatial and temporal changes of plankton communities. We are attempting to answer the question to what extent the zooplankton fauna is different in the externally well divided three river sections. We investigated the zooplankton components based on temporal changes because since the 1970s considerable effects - both positive and negative - have been modifying the fauna composition in the river. Our goal is not to create artificial borders but to demonstrate and analyse the existence of spatial and temporal changes with the help of statistical methods. One more aim is to compare the RSD to other essential Hungarian water bodies based on the zooplankton fauna. The stagnant water character of the river arm suggests that the RSD may have several similar features concerning its fauna to the lakes involved in the study.

\section{Review of literature}

The first study concerning the zooplankton of the RSD was published in 1956 [2] which expressly deals with plankton crustaceans, respectively with the nutrition supply disposable for fishes. Notwithstanding that the surveys were carried out at a stretch of 2 
kilometres (river $\mathrm{km} \mathrm{20-22)}$ ) and 3 sampling sites were designated, it counts as a fresh ground for RSD research. The individual numbers of plankton crustaceans were low throughout the year with the exception of June when the abundance was higher. The low abundance was interpreted by the permanent pollution. Present authors stated that the river arm as a considerably eutrophicated water deserves top interest. Based on the gut contents of fishes Leydigia leydigi, Iliocryptus sordidus, Leptodora kindtii and Cyclops vicinus were the main nutrients for fishes besides the chironomids.

Schiefner and Urbányi [42] performed also plankton surveys under complex hygiene examination of the river arm. They pointed out that the abundance of plankton organisms increased gradually from Pesterzsébet up to Tass, highest individual number was found in May. 17 Rotatoria species were identified, the water quality was betamesosaprobic based on saprobiological evaluation.

Bothár in her work, published in 1973 [3], analysed the zooplankton samples taken once in a fortnight, for one year, at 3 sampling sites (Soroksár, Dunaharaszti, Ráckeve). At each sampling site occured two peaks: end of May-early June respectively end of August-early September. The author set out that the upper river stretch (Dunaharaszti and Soroksár) has a similar fauna and low individual numbers as compared to the lower stretch, where more species occur and with higher abundance (abundance increased by 30-fold). Previous difference was explained by the pollution of the upper river stretch. The temporal variation of the copepod and cladoceran community was also presented. According to Bothár quantitative and qualitative differences exist among copepod and cladoceran standing stock. During the survey 38 Cladocera and 14 Copepoda species were recorded.

Gulyás and Tyahun [19] similarly investigated the Crustacea plankton of the RSD, samplings conducted between May and October 1970 from four sites (Szigethalom, Ráckeve, Dömsöd, Tass). The fauna of reedgrass vegetation was examined both quantitatively and qualitatively, additionally saprobity was estimated. However the authors came to the conclusion that the saprobiological evaluation based on crustacean led to unreal notion in the RSD (oligo-beta-mesosaprobic state). 28 Cladocera, 12 Copepoda and 2 Ostracoda species were identified from samples. In accord with the results of Bothár [3] both the abundance and species number increased around the lower river stretch. In the upper river stretch by Szigethalom, which is more polluted and muddy, are living common species with high level of adaptability. The quantitative and qualitative change of the Entomostraca fauna was identical along the whole section of the river arm. Copepods occur first in spring, their abundance decreases in summer and increases in autumn again. Contrarily cladocerans peaked in summer and autumn.

Győrbíró [20] dealt partly with cladocerans in his diploma work. Four sampling sites (Soroksár, Szigethalom, Ráckeve, Makád) were included in this research conducted between July and September. Results were compared to Berinkey-Farkas's [2] work. According to Győrbíró the abundance of plankton collected at Soroksár and Szigethalom were constantly decreasing during the survey, while at Ráckeve at first moderate then sharp increasing was followed by a sharp decreasing. It is worth mentioning the low number of Cladocera found by the writer.

Tyahun [44] announced data of Copepoda, Cladocera and Ostracoda from four locations (Szigethalom, Ráckeve, Dömsöd, Tass). In addition to the checklist, seasonal dynamics was also presented, namely copepods are among the first organisms inhabiting the reedgrass, they are characterized by spring and autumn peaks, 
cladocerans appear later with an abundance maximum in autumn, ostracods could reach the abundance of the order of one hundred thousand in August and September.

Bothár and Kiss [4] conducted phyto-and zooplankton investigations bimonthly at Ráckeve in 1983. They found less species than Bothár in 1970-71, and no other species turned up. The formerly dominant euplanktonic Bosmina longirostris occured rarely just as other Cladocera species characteristic previously. Summarized the results they came to the conclusion that the Ráckeve-Soroksár Danube arm has reached the eu-polytrophic state as compared to the meso-eutrophic, eutrophic state existing in 1970-71.

Gulyás [13] examined the Rotatoria and Crustacea plankton of the RSD and the main arm for one year. Rotifers were presented in the greatest abundance and also most species occured among Rotatoria. In the initial stretch of the river arm biomass and species composition were similar to the main branch, whereas 20-25 kilometres down increased the biomass notably. In the lower stretch biomass value characteristic for polytrophic stagnant water was measured.

Just et al. [21] dealt with comparing and co-ordinating the methods of water quality assessment used in Hungary and in Germany. In part of this study they carried out chemical, microbiological and faunistical examinations on the river Danube and on its side arm RSD. Five sampling sites were designated on the RSD (after Kvassay sluice, Dunaharaszti, Majosháza, Ráckeve, Dömsöd). The greatest zooplankton biomass was found at Ráckeve in June. Most zooplankton species occured among rotifers, 26 Copepoda and Cladocera species turned up in the river arm. Difference in species composition between the main branch and branch was interpreted by the different rate of flow (the lower stretch of the RSD has a character of stagnant water).

The qualitative and quantitative changes of Rotatoria and Crustacea plankton in the river Danube was published by Gulyás [15]. In this survey took part 10 researchers from different nations in order to examine the section of Danube between Neu-Ulm and Tulcea incorporating 2581 kilometres. Examinations trended not only to chemical water quality evaluation, but also following the ecological state of the water with attention, in tune with the Water Framework Directive. In the RSD high abundance and low number of species were found during the survey. Rotatoria and Crustacea species characteristic of polytrophic water bodies were presented. Present survey was also published as a summary report ,Joint Danube Survey” [27].

The basis of this synthesis is the material compiled in our previous works [30, 45], a complex ecological review and evaluation of the RSD arm is also available [46]. Table 1 shows the zooplankton surveys which have significant faunistic results. 
Table 1. Overview of researches carried out in the RSD in faunistic point of view. Abbreviations: Pe - Pesterzsébet; Sor - Soroksár; Dh - Dunaharaszti; Szh Szigethalom; Szsz - Szigetszentmiklós; Szcs - Szigetcsép; Kisk - Kiskunlanháza; MajMajosháza; Mak — Makád; Gub - Gubacsi bridge; Szm — Szigetszentmárton; Ráck — Ráckeve; Döm-Dömsöd; Tass - Tass.

\begin{tabular}{|c|c|c|c|c|c|c|}
\hline \multirow[b]{2}{*}{ Author } & \multirow[b]{2}{*}{ Sampling site } & \multirow{2}{*}{$\begin{array}{c}\text { Sampling } \\
\text { date }\end{array}$} & \multicolumn{4}{|c|}{ Number of taxa } \\
\hline & & & Cladocera & Copepoda & Ostracoda & Rotatoria \\
\hline $\begin{array}{c}\text { Berinkey and } \\
\text { Farkas (1956) }\end{array}$ & Ráck & 1953-54 & 14 & 6 & 4 & \\
\hline $\begin{array}{l}\text { Schiefner and } \\
\text { Urbányi (1970) }\end{array}$ & $\begin{array}{l}\text { Pe,Dh,Szsz,Maj,Ki } \\
\text { sk,Ráck,Döm,Tass }\end{array}$ & $1966-67$ & & & & 17 \\
\hline Bothár (1973) & Sor,Dh,Ráck & 1969-71 & 38 & 14 & & \\
\hline $\begin{array}{c}\text { Gulyás and } \\
\text { Tyahun (1974) }\end{array}$ & $\begin{array}{c}\text { Szh,Ráck,Döm,Tas } \\
\text { s }\end{array}$ & 1970 & 28 & 12 & 2 & \\
\hline $\begin{array}{c}\text { Györbíró } \\
\text { (1974) }\end{array}$ & Sor,Szh,Ráck,Mak & 1974 & 2 & 4 & & 10 \\
\hline Tyahun (1977) & $\begin{array}{c}\text { Szh,Ráck,Döm,Tas } \\
\text { s }\end{array}$ & 1970 & 23 & 11 & 2 & \\
\hline $\begin{array}{l}\text { Gulyás (1997), } \\
\text { Just et al.(1998) }\end{array}$ & $\begin{array}{l}\text { Kv,Dh,Maj,Ráck,D } \\
\text { öm }\end{array}$ & 1995-96 & 17 & 9 & & 36 \\
\hline $\begin{array}{c}\text { Mészáros (not } \\
\text { published) }\end{array}$ & $\begin{array}{c}\text { Kv,Gub,Dh,Szh,Sz } \\
\text { cs,Szm,Ráck,Döm, } \\
\text { Tass } \\
\end{array}$ & 2005 & 30 & & & \\
\hline $\begin{array}{l}\text { Vadadi-Fülöp } \\
\text { (not published) }\end{array}$ & Sor,Dh & 2006-07 & 10 & 4 & & \\
\hline
\end{tabular}

\section{Materials and methods}

Our examination is analysing the zooplankton fauna from the 1950s up to now. As few quantitative data are available this work is dealing only with qualitative data (presence - absence). We set up a zooplankton faunistic database based on data from literature and our measurements. We made charts of the data and classified them according to the time of sample taking (50-70s and 90-00s) and sampling sites: river sections (upper, middle, lower) and settlements.

There was no opportunity for a more precise classification since not all the publications have usable data. We have valuable information about the zooplankton fauna of the 1950s, 1960s and 1970s from the publications performed by Berinkey and Farkas [2], Bothár [3], Gulyás and Tyahun [19], Györbíró [20] and Tyahun [44]. As for the 90-00s we used data from the publications presented by Gulyás [13], Just et al. [21]. In addition we could make good use of our own surveys (Mészáros 2005, Vadadi-Fülöp 2006-2007, not published). We decided on this classification because the data, we can use and evaluate, are mainly in accordance with these two aspects (spatial and temporal) and moreover they can be the basis for a clear comparison. While analysing we had to leave out the Rotatoria taxa because only one detailed survey of them was carried out in 1995-1996 [13, 21]. We have no ground for comparison though it was a comprehensive investigation as 36 taxa were found at 5 sampling sites. So only Copepoda and Cladocera are presented in the analyses. As for Copepoda fauna so far only two species of Harpacticoida suborder have been found in this section of the Danube, even so they are not described in the comparison as most of the studies do not deal with them. Ostracoda is also ignored for the same reasons. 
The above-mentioned database was completed with the Copepoda and Cladocera fauna of some important Hungarian water bodies: the Danube (without Szigetköz), the Danube (with Szigetköz), the Tisza, the Rába, the Dráva, Lake Balaton, Lake Velence, Lake Fertö (Fig. 2). The Danube (without Szigetköz) means that the main arm of the Danube is considered and the water bodies of Szigetköz are neglected, respectively the Danube (with Szigetköz) includes the different water bodies of Szigetköz. Previous division seems to be necessary since in the Szigetköz region several rare species can be found without occurrence in the main arm. For these waters the database was compiled based on the works of Megyeri [29], Zánkai and Ponyi [48], Gulyás and Forró [17, 18], Ponyi [32, 36], Körmendi and Lanszki [26], Kiss [23], Zsuga et al. [49], Nedelkovics and Zsuga [31). So altogether 126 species are included in the study.

Data were analysed with multivariate statistical methods (cluster analysis and ordination) performed with Past software (Hammer and Harper 1999-2005).

Characterization of the species is based on the following works: Einsle [5], Flössner [6], Forró and Gulyás [7], Kiefer and Fryer [22], Korovchinsky [24], Rylov [41], Smirnov [43], Gulyás and Forró [17, 18]. The taxonomic system of Gulyás and Forró $[17,18]$ was observed throughout the study, whereas saprobiological estimation is based on Gulyás's [14] work.

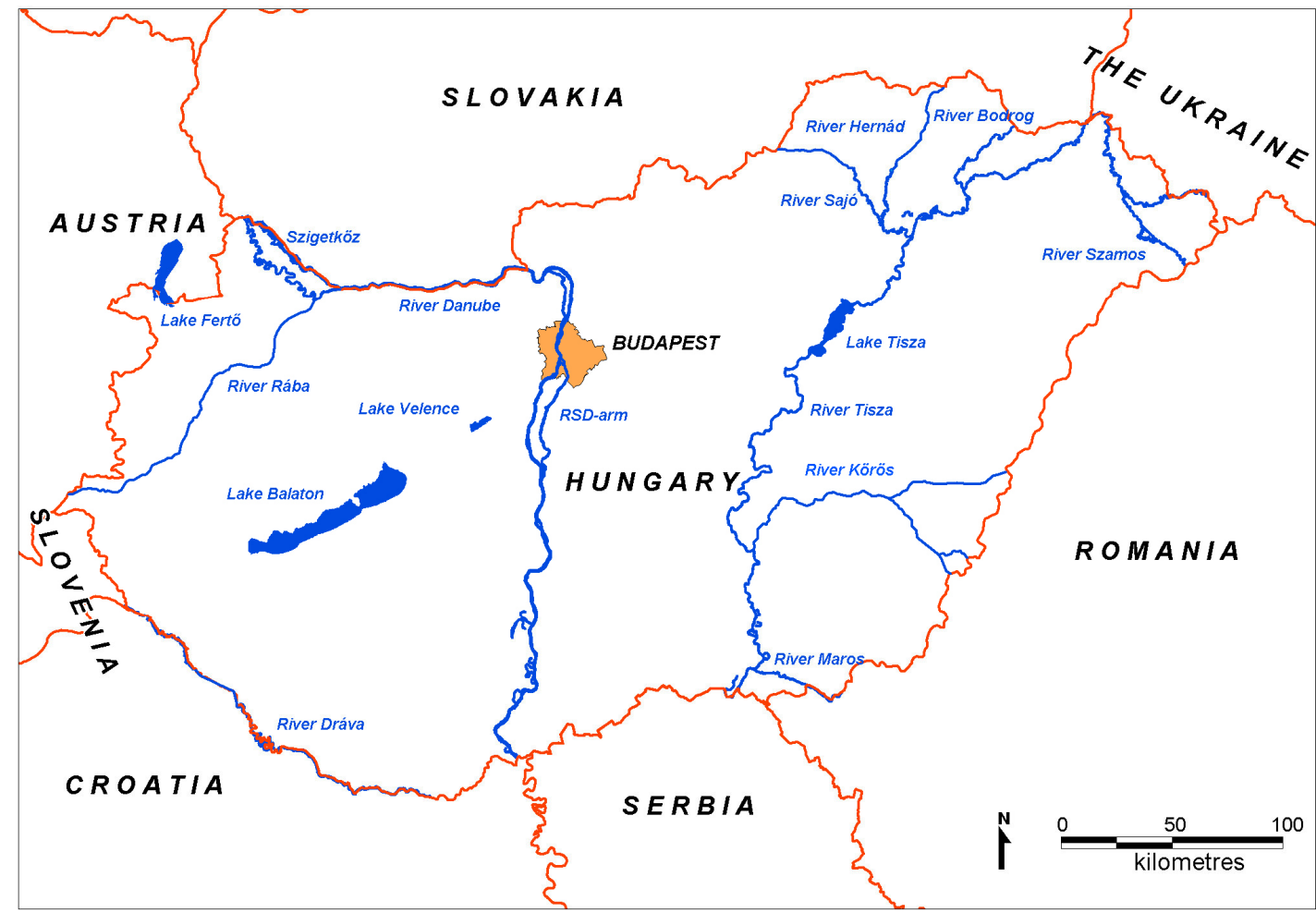

Figure 2. Map of the main water bodies in Hungary.

\section{Results}

\section{Spatio-temporal changes of the zooplankton community}

In the RSD arm we managed to reveal 66 different Copepoda and Cladocera species on the basis of our examination and the data from literature we dealt with. Out of these species 61 can be found in the lower section located between Ráckeve and Tass, 37 
species can be observed in the stretch extending between Szigethalom and Ráckeve. In the upper section, between Szigethalom and Kvassay sluice 41 species were described. Out of the 66 species in question 25 can be found in all the sections above. One of Copepoda species, Graeteriella unisetigera (Graeter, 1908) has not been found so far anywhere else in Hungary [18]. The habitat of this species is in subsoil waters, caves, wells, interstitial waters and it is highly abundant in Central Europe. In 1974 Györbíró presented this species in all the three sections of the RSD arm but his results were not published. In Table 2 we revised the species we investigated on the basis of literature and our data. Next to the species the years of their presence in the RSD arm can be seen. On the right the river sections where the species were described can be found.

Table 2. The zooplankton (Copepoda, Cladocera) fauna of the RSD and its spatio-temporal changes.

\begin{tabular}{|c|c|c|c|c|c|}
\hline Taxa & $50-70 s$ & 90-00s & lower & middle & upper \\
\hline Oxyurella tenuicaudis (Sars, 1862) & + & & + & & \\
\hline Alonella exigua (Lilljeborg, 1853) & & + & & & + \\
\hline Alonella nana (Baird, 1850) & & + & & & + \\
\hline Anchistropus emarginatus Sars, 1862 & + & + & + & & \\
\hline Bosmina longirostris (O. F. Müller, 1785) & + & + & + & + & + \\
\hline Bosmina coregoni Baird, 1857 & + & + & + & & + \\
\hline Camptocercus rectirostris Schoedler, 1862 & + & + & + & + & + \\
\hline Leptodora kindtii (Focke, 1844) & + & & + & & + \\
\hline Sida crystallina (O. F. Müller, 1776) & + & + & + & + & \\
\hline Diaphanosoma brachyurum (Liévin, 1848) & + & + & + & & + \\
\hline Daphnia cucullata Sars, 1862 & + & + & + & + & + \\
\hline Daphnia hyalina Leydig, 1860 & + & + & + & & \\
\hline Daphnia pulex Leydig, 1860 & + & & + & & \\
\hline Daphnia longispina O. F. Müller, 1785 & + & + & + & + & + \\
\hline Disparalona rostrata (Koch, 1841) & + & + & + & + & + \\
\hline Eurycercus lamellatus (O. F. Müller, 1785) & + & + & + & + & + \\
\hline Graptoleberis testudinaria (Fischer, 1848) & + & & + & + & \\
\hline Simocephalus serrulatus (Koch, 1841) & + & & + & & \\
\hline Simocephalus expinosus (Koch, 1841) & + & & + & & \\
\hline Simocephalus vetulus (O. F. Müller, 1776) & + & + & + & + & + \\
\hline Moina macrocopa (Straus, 1820) & + & & + & & \\
\hline Moina micrura Kurz, 1874 & + & + & + & + & + \\
\hline Moina brachiata (Jurine, 1820) & + & & + & + & \\
\hline Monospilus dispar Sars, 1862 & + & & + & & \\
\hline Ceriodaphnia quadrangula (O. F. Müller, 1785) & + & + & + & + & \\
\hline Ceriodaphnia dubia Richard, 1894 & + & + & + & + & + \\
\hline Ceriodaphnia laticaudata P. E. Müller, 1867 & + & + & + & & + \\
\hline Ceriodaphnia pulchella Sars, 1862 & + & & + & & \\
\hline
\end{tabular}




\begin{tabular}{|c|c|c|c|c|c|}
\hline Taxa & $50-70 \mathrm{~s}$ & 90-00s & lower & middle & upper \\
\hline Scapholeberis mucronata (O. F. Müller, 1785) & + & + & + & + & + \\
\hline Macrothrix laticornis (Fischer, 1848) & + & & + & & + \\
\hline Macrothrix hirsuticornis Norman \& Brady, 1867 & & + & & + & + \\
\hline Iliocryptus sordidus (Liévin, 1848) & + & + & + & & \\
\hline Iliocryptus agilis Kurz, 1878 & + & + & & + & + \\
\hline Acroperus harpae (Baird, 1834) & + & + & + & + & + \\
\hline Pleuroxus truncatus (O. F. Müller, 1785) & + & + & + & + & + \\
\hline Leydigia leydigi (Schoedler, 1863) & + & + & + & & + \\
\hline Chydorus sphaericus (O. F. Müller, 1776) & + & + & + & + & + \\
\hline Pleuroxus trigonellus (O. F. Müller, 1785) & + & + & + & + & + \\
\hline Pleuroxus uncinatus Baird, 1850 & + & + & + & & + \\
\hline Pleuroxus aduncus (Jurine, 1820) & + & + & + & + & + \\
\hline Pseudochydorus globosus (Baird, 1843) & + & + & + & + & \\
\hline Alona quadrangularis (O. F. Müller, 1785) & + & + & + & + & + \\
\hline Alona affinis (Leydig, 1860) & + & + & + & + & + \\
\hline Alona intermedia Sars, 1862 & + & + & + & + & \\
\hline Alona guttata Sars, 1862 & + & + & + & & \\
\hline Alona rectangula Sars, 1862 & + & + & + & + & + \\
\hline Macrocyclops albidus (Jurine, 1820) & + & + & + & + & \\
\hline Macrocyclops fuscus (Jurine, 1820) & + & & + & & \\
\hline Eucyclops serrulatus (Fischer, 1851) & + & + & + & + & + \\
\hline Eucyclops macruroides (Lilljeborg, 1901) & + & & + & & \\
\hline Eucyclops macrurus (Sars, 1863) & + & & + & + & \\
\hline Paracyclops fimbriatus (Fischer, 1853) & + & + & + & & + \\
\hline Cyclops strenuus Fischer, 1851 & + & & + & & + \\
\hline Cyclops vicinus Uljanin, 1875 & + & + & + & + & + \\
\hline Graeteriella unisetigera (Graeter, 1908) & + & & + & + & + \\
\hline Megacyclops viridis (Jurine, 1820) & + & & + & + & \\
\hline Acanthocyclops vernalis (Fischer, 1853) & + & & + & + & + \\
\hline Acanthocyclops robustus (Sars, 1863) & + & + & + & + & + \\
\hline Diacyclops bicuspidatus (Claus, 1857) & + & & & & + \\
\hline Cryptocyclops bicolor Sars, 1927 & + & & + & & \\
\hline Mesocyclops leuckarti (Claus, 1857) & + & & + & + & + \\
\hline Thermocyclops crassus (Fischer, 1853) & + & + & + & + & + \\
\hline Thermocyclops oithonoides (Sars, 1863) & & + & + & + & \\
\hline Eudiaptomus gracilis (Sars, 1863) & + & + & + & & + \\
\hline Eurytemora velox (Lilljeborg, 1853) & & + & + & & + \\
\hline Ectocyclops phaleratus (Koch, 1838) & & + & + & & \\
\hline
\end{tabular}


In the following we are describing the $3 \mathrm{RSD}$ arm sections on the basis of Copepoda and Cladocera fauna and then on the basis of spatial and temporal changes.

\section{The upper section}

According to our examinations and the data from literature 41 species can be identified in the upper river section. It is extremely remarkable that merely 3 of the 41 species can be regarded typical of this river stretch (Alonella exigua, Alonella nana, Diacyclops bicuspidatus). Alonella exigua can be described as a species closely confined to reedgrass and its sparse existence can be announced mainly in peaceful, hidden places and creek. There is no record of their presence in the RSD arm in the period of the 50-70s. In the meantime based on our survey we can say that Alonella exigua is relatively common both in the main and side arms at Dunaharaszti. Alonella nana is a resistant cladoceran and is presented in a large variety of waters. Its size makes the species capable of living in every place where detritus occurs. In spite of the fact that this section of the RSD arm has the most sources of pollution it must be mentioned that Alonella nana is announced to be sensitive to pollution. The third species, Diacyclops bicuspidatus prefers waters that are rich in organic substance.

Further species that can be found in this river section: Bosmina longirostris is a species of the highest abundance in small, eutrophic lakes, on the other hand it avoids polluted waters, commonly characteristic of beta-mesosaprobic waters. Disparalona rostrata lives in detritus accumulated in soft, deep mud. Pleuroxus aduncus is cosmopolitan and is the inhabitant of eutrophic waters. Acanthocyclops vernalis is a copepod of high abundance all over Central Europe. Upon these facts we can come to the conclusion that the upper river stretch of the RSD is the most polluted but the rate of pollution is not extreme as e.g. Bosmina and Alonella species avoid highly polluted waters.

According to the species described hereby the upper section is a moderately - highly polluted water where the signs of advanced eutrophication can be observed as the species described here like eutrophic waters. Leydigia leydigi must be mentioned as a species that has adapted so much to the circumstances with oxygen deficiency that even haemoglobin is present in its lymph.

If we take temporal changes into consideration when investigating Cladocera and Copepoda fauna, we can come to an interesting conclusion: based on the available data we can state the presence of 30 different species in the upper section and they were announced both in the 50s $-70 \mathrm{~s}$ and $90 \mathrm{~s}$. There are only 7 species of them that were described only in the $60 \mathrm{~s}$ in this section of the RSD arm, 5 species belong to Copepoda subclass and only 2 belong to Cladocera order. One of them is the rather scarce Leptodora kindtii, the only representative of Leptodoridae in Hungary. This species has considerable sizes $(6-7 \mathrm{~mm})$ that make it a real giant among Cladocera. Studying the needs and the habitats of these species we can see that they are the same more or less even nowadays. Mesocyclops leuckarti e.g. is the inhabitant of mainly eutrophic lakes, Diacyclops bicuspidatus likes waters rich in organic substance. Macrothrix laticornis lives mainly in the muddy bottom sediment of puddles and small lakes or among vegetation in moderately eutrophic waters. We have already described the needs and habitat of Alonella exigua and Alonella nana. In the 90s these two species were announced in the upper section just as Macrothrix hirsuticornis that can be described as the inhabitant of the shore zones of the most various waters. The occurrence of 
Thermocyclops oithonoides is the most remarkable fact in this river section. It can be observed mainly in large stagnant waters, needs oxygen and shows meso-oligotrophy. In any case it is strange that an oxygen demanding species was stated in this river stretch.

On the whole if we examine the species presented above in accordance with temporal changes we cannot see considerable differences between the conditions of 50-70s and 90-00s. There are no significant changes in fauna composition. This fact is worth mentioning as numerous sources of pollution have ceased since the $60 \mathrm{~s}$ and in addition the importance of transportation has declined on this waterway. So the water in the main arm of the Danube seems to determine the water quality in the upper section of the RSD arm just as 40 years ago.

\section{The middle section}

In the middle section the number of species is the lowest (only 37 described species). It is interesting that there are no species exclusively characteristic of this section. All of the species here can be found either in the upper or the lower section and some species can be observed in both. This fact means the transient feature of the middle-section. It is conspicuous that Ceriodaphnia quadrangula can be observed in this river stretch as this species is sensitive to pollution and eutrophication. The occurrence of Moina micrura is pleasing. This species contrasted with the other Moina species exists in cleaner waters that are less polluted by organic substance. In spite of this fact it was described in the river section both in the 50-70s and 90-00s. These facts show that the effect of pollution is less dominating and self - purification process can be considerable in this section.

We can observe bigger differences in temporal examinations rather than in comparing the species composition of this section with that of the other two sections. There are 7 species described in the 50-70s but they are not presented in the 90s. In contradiction to this there are only 2 species present only in the 90s. Eucyclops macrurus lives sparsely and likes waters that are rich in vegetation. So in spite of the fact that this species was not identified in the 90s probably it has not vanished from the RSD arm as its vital conditions have not declined. Grabtoleberis testudinaria - also presented in the RSD arm in the 50-70s - is the inhabitant of the coastal phytoid zone of larger lakes and rivers. Its presence has been announced in many places but it likes mainly the acid, poor water of swamps. Mesocyclops leuckarti also can be found on the checklist of the 50-70s though it is the inhabitant of eutrophic waters while Moina micrura prefers cleaner waters. In spite of these facts both of them were described in the middle section of the RSD arm. It is worth mentioning that Mesocyclops leuckarti was presented in all the three sections in the 50-70s. We must remark that in 2007 during our investigations we could observe this species in a side-arm of the RSD arm. Megacyclops viridis was also presented only in the 50-70s. Though this species is cosmopolitan and common everywhere, in the 90s it was not described in the sections of the RSD arm. The tendency is similar as for Graeteriella unisetigera. The data from literature show its occurrence in the three sections of the RSD arm in the 50-70s but it was not announced in the 90s. It is really interesting that this species exists in subsoils and in the water of caves, wells i.e. in places where the water is rich in oxygen and gets little light. Probably its occurrence is unique and sparse. Thermocyclops oithonoides was described in the middle section only in the 90s. This species demanding oxygen prefers the extended, stagnant water and shows meso-oligotrophy. Macrothrix hirsuticornis is not confined to oxygen so much even it is a characteristic of sodic 
waters. It is the inhabitant of a great variety of waters mainly in the coastal zone covered by vegetation or it occurs close to the river bed.

Based on the above mentioned facts we can state that the middle section cannot be sharply seperated from the other two river sections considering the fauna composition as there are not any species exclusively found in it. We must add that the middle section offers the most various habitats. Large, open body waters can be found here as well as hidden creeks and - as the shores are partly in the original state - a great variety of coastal vegetation extends. That is why all species can find their vital conditions in the middle river section.

If we examine temporal changes the situation is different. Seven species were described in the 50-70s and they were not in the 90s. Most of them are of high abundance. So we can come to the conclusion that some species have vanished not because the water quality has changed but because the other, less sensitive, cosmopolitan species have displaced them slowly.

\section{The lower section}

According to the literature the lower section has the highest number of species. From the 50-70s 58 different species have been recorded. There are 15 species that exist or existed only in this section. This number can be regarded significant. Anchistropus emarginatus, Monospilus dispar, Ectocyclops phaleratus also belong to the group above. All the three species are scarce, so their presence in this river stretch is really special. Ectocyclops phaleratus lives mainly in small waters while Anchistropus emarginatus and Monospilus dispar like stagnant waters and waters with low current velocity. The former lives on hydras and feeds on their tissues. Ceriodaphnia pulchella likes clean, small waters that are free of pollution based on organic matter content. Eutrophication is the biggest problem in the RSD arm so the presence of Ceriodaphnia pulchella is very important as this species restricts eutrophication. The fact that the three species above and Ceriodaphnia pulchella can be found in the lower section means that the water quality is favourable.

Daphnia hyalina is reported as an inhabitant of deep, moderately calcareous lakes, reservoirs and shallow lakes with large surface.

Alona guttata was also presented exclusively in the lower section. This species is resistant and common so much that it was identified even in the collected water of hollow trees. In most cases however Alona guttata can be observed in the vegetation of reeds or in muddy circumstances with reedgrass. A lot of places of this kind can be found in the other two sections so its exclusive presence in the lower section is unusual. Oxyurella tenuicaudis likes habitat that is quiet and rich in vegetation, where the water is smaller, swamps are characteristic and lives in the submerged vegetation. Based on the data from literature its presence only in this river section is surprising.

So far Cryptocyclops bicolor and Eucyclops macruroides - the representatives of Copepoda - have been announced mainly in lakes and small waters.

Comparing the fauna composition in the lower section with those in the other two sections we can see remarkable differences as for the 15 species living only in the lower section. In addition there are scarce species among them and many of them like clean, unpolluted water. Moreover Ceriodaphnia pulchella is definitely described by literature as an eutrophication restrictive species. Another similarity of species is that most of them are the inhabitants of stagnant water or water of low current velocity. This reflects 
the present conditions entirely i.e. the lower section of the RSD arm can be regarded as a stagnant water.

When considering temporal comparison even more significant differences must be mentioned. In the 50-70s 20 species were pointed out and they were not described in the 90-00s. On the other hand only three species were described during the investigations in the 90-00s. All these three species (Thermocyclops oithonoides, Eurytemora velox, Ectocyclops phaleratus ) belong to Copepoda. Eurytemora velox definitely has been the member of the home fauna for 16 years. Its first occurrence was reported from Szigetköz in 1991. Ectocyclops phaleratus - scarce species, Thermocyclops oithonoides - oxygen demanding species, the inhabitant of bigger, stagnant waters, show meso oligotrophy.

Going on with the analysis of Copepoda - based on literature - we can find 10 species described in the 60s in the RSD arm and not identified in the 90s. Mesocyclops leuckarti - presented mainly in eutrophic waters - has not been reported recently. Megacyclops viridis and Acanthocyclops vernalis are common species. Similary, it is surprising that Alona guttata was described in 50-70s and it has not been reported since then. Graeteriella unisetigera was described in the 50-70s in both the middle and lower section. Probably only few of them were found. Cyclops strenuus is very resistant and can adapt well to pollution and the changes of conditions. So probably the stock of them existing in this river section was not small yet their presence was not announced in the 90s. We must remark that the absence of some species does not mean that they have vanished but it may be a mistake when taking samples as scarce species do not always occur in samples. Macrothrix laticornis was the representative of Cladocera in the 50$70 \mathrm{~s}$. On the basis of literature it is the habitant of puddles, smaller lakes, dead arms, shallow water. This species - just as some others - may have been displaced from its habitat. Probably the some happened to Ceriodaphnia pulchella. It is the habitant of clean, smaller waters and restricts eutrophication. So the absence of this species is unfortunate. Whereas Simocephalus serrulatus was identified only in this river stretch. It lives in smaller waters (lakes, puddles, creeks, ditches) and prefers to stay in vegetation, where the water contains colloidal organic substance.

To sum up we can state that the lower section of the RSD arm is definitely from the other two ones as numerous species can be observed only in this river stretch. Although in the course of time the number of species has decreased it is still different from the middle and upper sections of the RSD arm.

In all the three sections the dominance of oligo-beta mesosaprobic species can be observed, especially regarding the lower section. However some species are characteristic of alfa-beta mesosaprobic or beta-mesosaprobic waters. Neither remarkable temporal nor spatial change in the saprobic state of the RSD could be stated based on Crustacea indicator species.

\section{Statistical analysis of the spatio-temporal changes}

We attempted to explore the spatio-temporal changes of the zooplankton community with multivariate statistical methods. Cluster analysis and non-metric multidimensional scaling (NMDS) were performed using Euclidean distance in both cases. The results of the former methods were compared to verify their efficiency. We considered examining the spatial and temporal patterns meaningful simultaneously, thus we can answer 
whether the spatial or the temporal changes are larger. The similarity patterns of the main sampling sites were also carried out with the same methods.

The dendogram of the sections and the 50-70s respectively 90-00s is presented in Fig. 3 based on the cluster analysis. For comparison the zooplankton fauna of the river Danube is represented with the water bodies of Szigetköz and without Szigetköz. It is evident that the river Danube isolated from the RSD. The result, that the fauna of the lower section is similar to the 50-70s likewise the fauna of the upper section is similar to the $90-00$ s is interesting. The middle section is near to the latter group. The transient character of the middle section was already apparent by the review of the species since no taxa were found existing only here. Particularly great similarity showed the 50-70s with the lower section on the grounds of their zooplankton fauna. The same result can be observed on the NMDS ordination (Fig. 4), the middle section is located between the other two sections. The fauna of the Danube without the water bodies of Szigetköz is closer to the RSD which can be interpreted by the species living in the Szigetköz area, namely there are many rare species not occurring in the RSD. Fig. 5 shows the Shepard plot of the ordination.

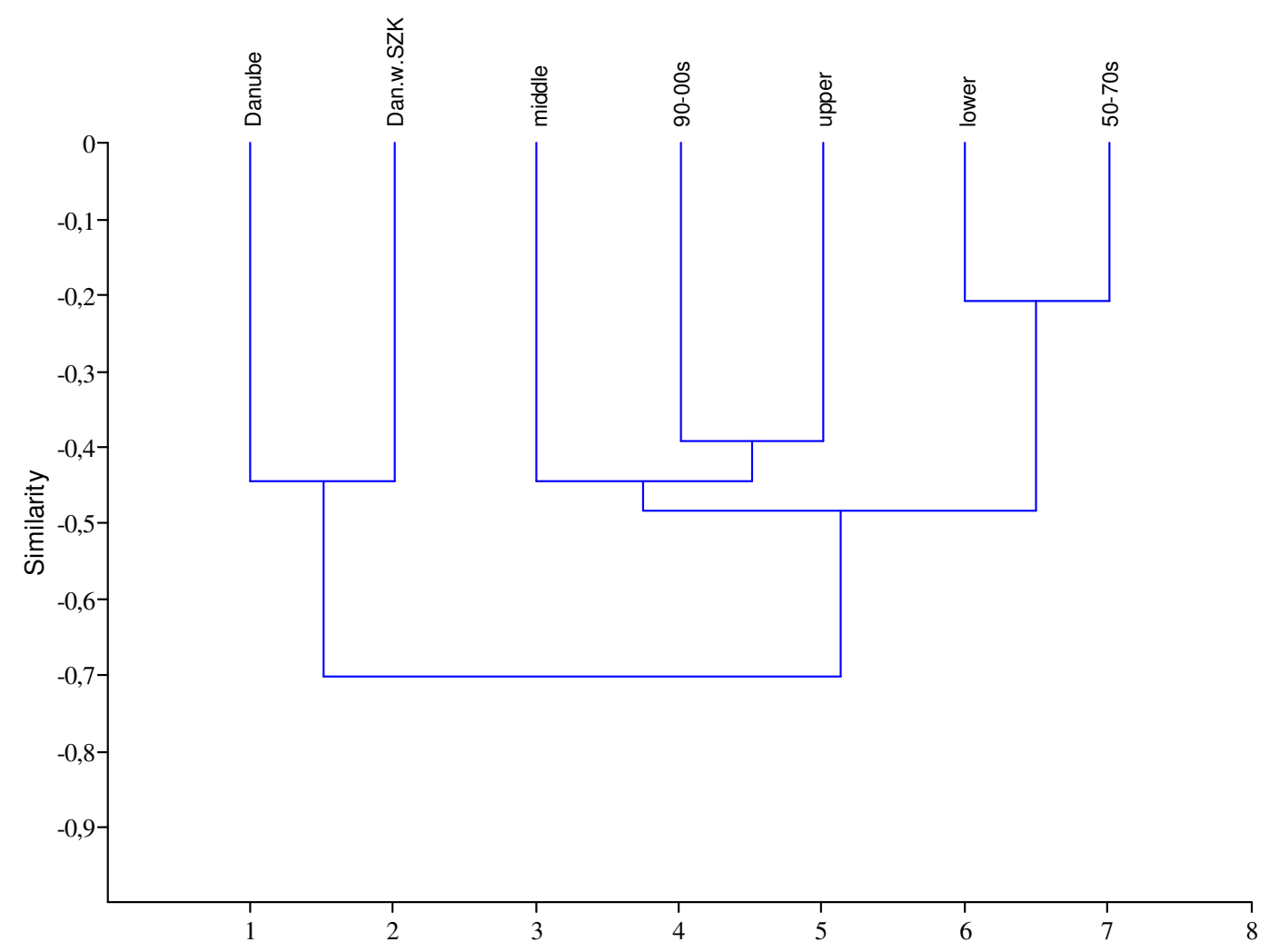

Figure 3. Dendogram of the sections and sampling dates (Euclidean distance). 


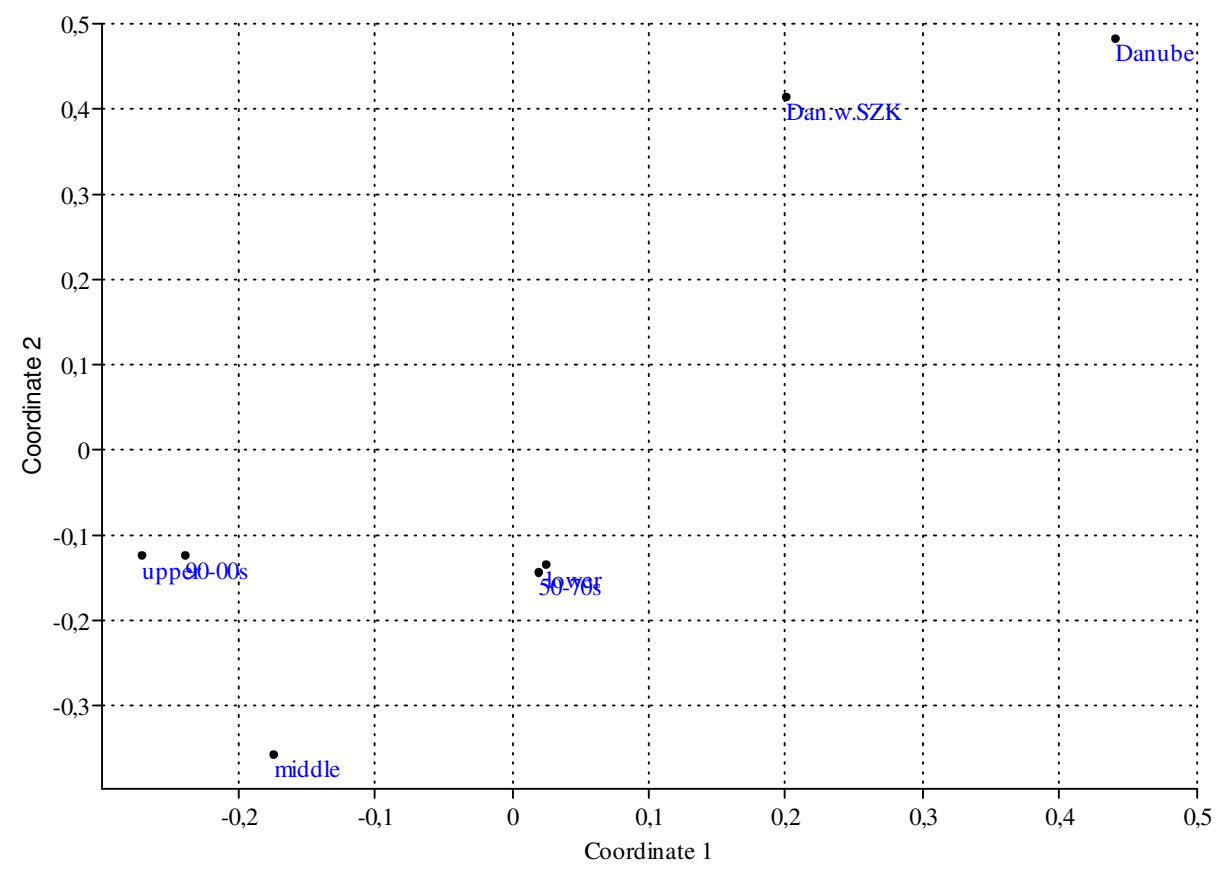

Figure 4. The NMDS ordination of the sections and sampling dates (Euclidean distance).

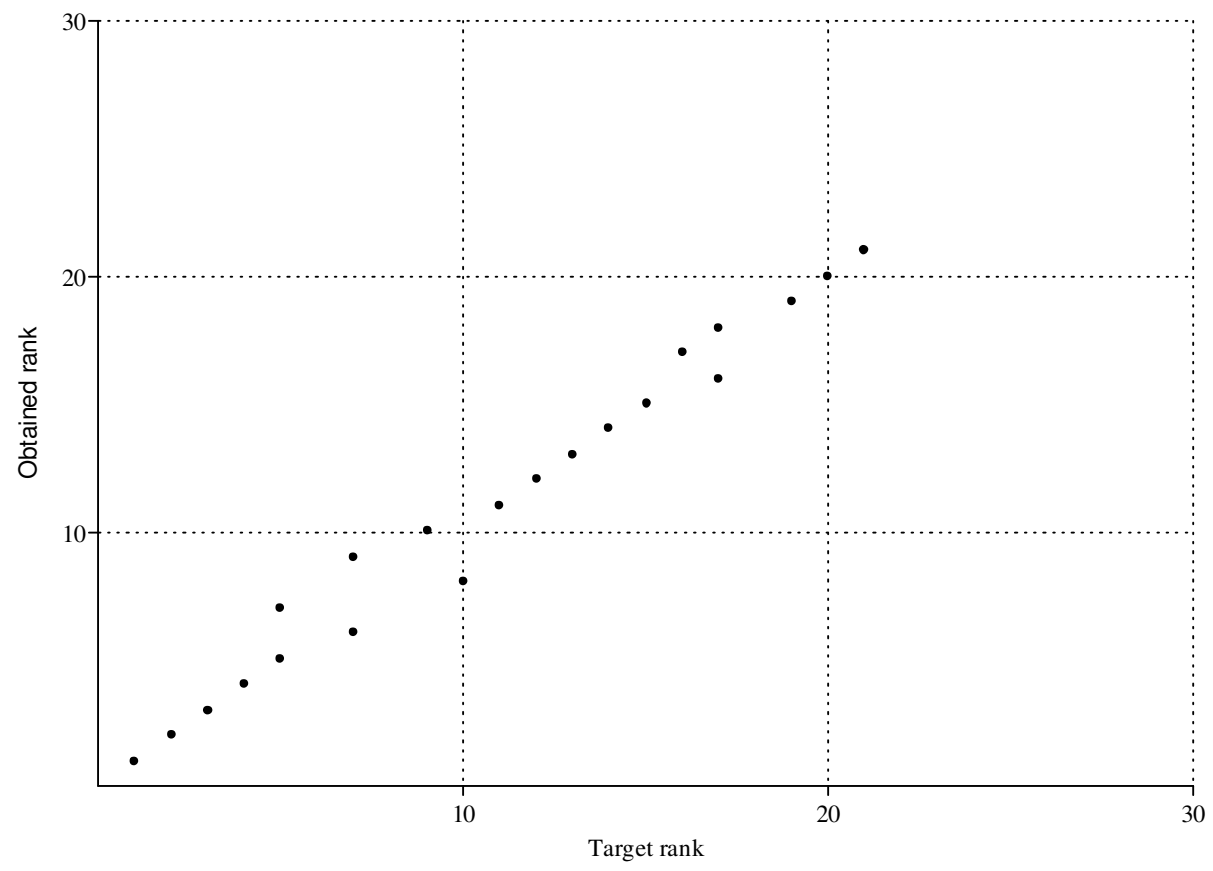

Figure 5. Shepard plot of the NMDS ordination of the sections and sampling dates (Stress: 0,07165). 
The main sampling sites, where sufficient number of surveys were conducted for making correct conclusions, were also classified. Sampling sites were the following: Kvassay sluice (Kv), Soroksár (Sor), Dunaharaszti (Dh), Szigethalom (Szh), Majosháza (Maj), Ráckeve (Ráck), Dömsöd (Döm), Tass (Tass). The fauna of the three sections are represented as references (Fig. 6, Fig. 7, Fig. 8). Our results showed that the fauna of the lower section is very similar to that of Ráckeve, which were sharply isolated from the other sampling sites and were characterized by the highest number of species. The sampling sites of Soroksár, Dunaharaszti and the upper section formed one group whit the associating Kvassay sluice and Majosháza, which from the ulterior belongs actually to the middle section. Majosháza is the bound of the upper and middle section, thus its position is not so surprising. Least species were found by Majosháza and Kvassay sluice and these were relative common species. Upper section is characterized by many common, pollution-resistant species. The third main group is the middle section, however it contains the sampling sites of Tass and Dömsöd as well. Neither several common species nor many rare species are living here. To sum up the statements the three typical sections seem to be isolated in point of the sampling sites, some deviation exist though.

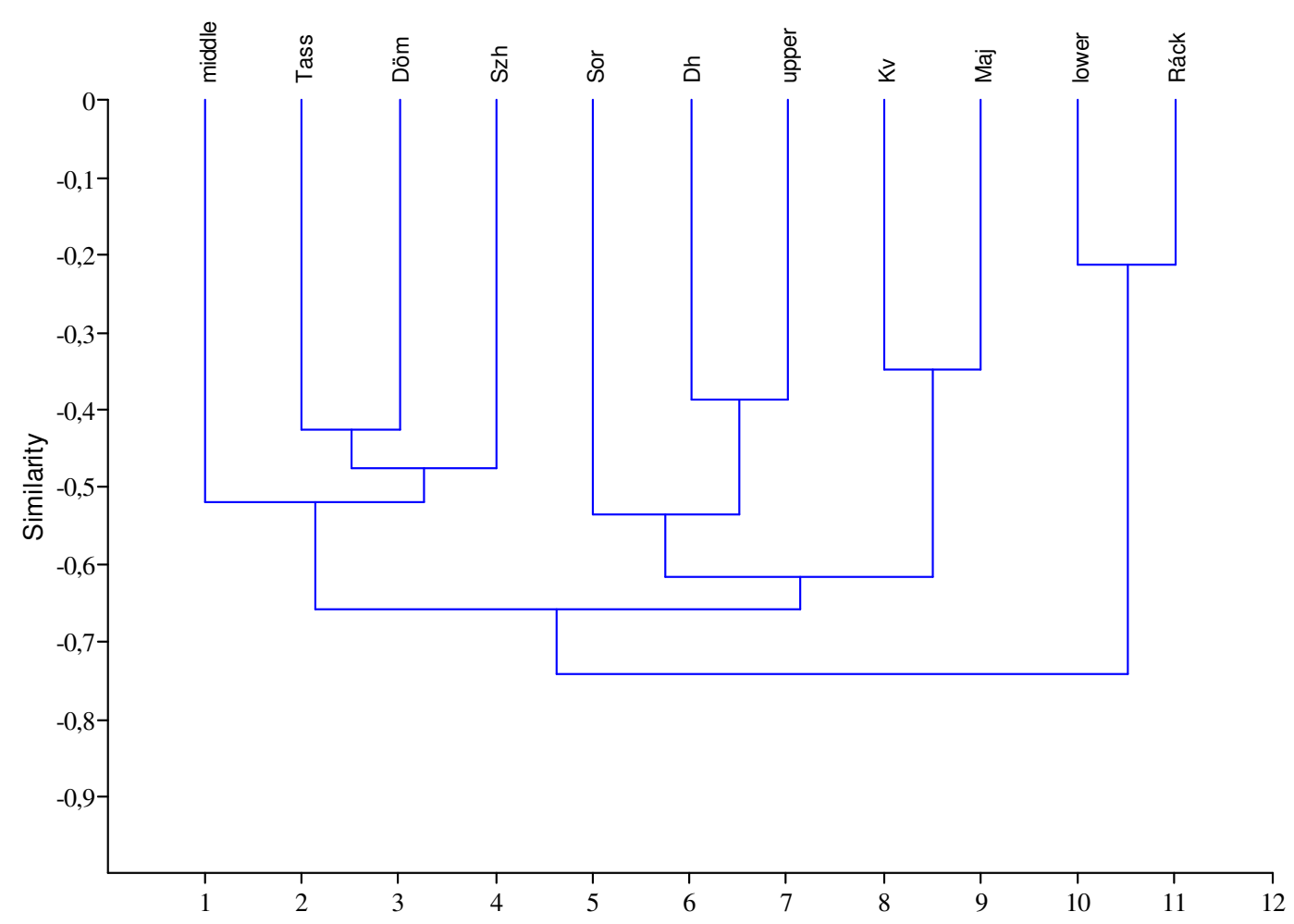

Figure 6. Dendogram of the sampling sites (Euclidean distance). 


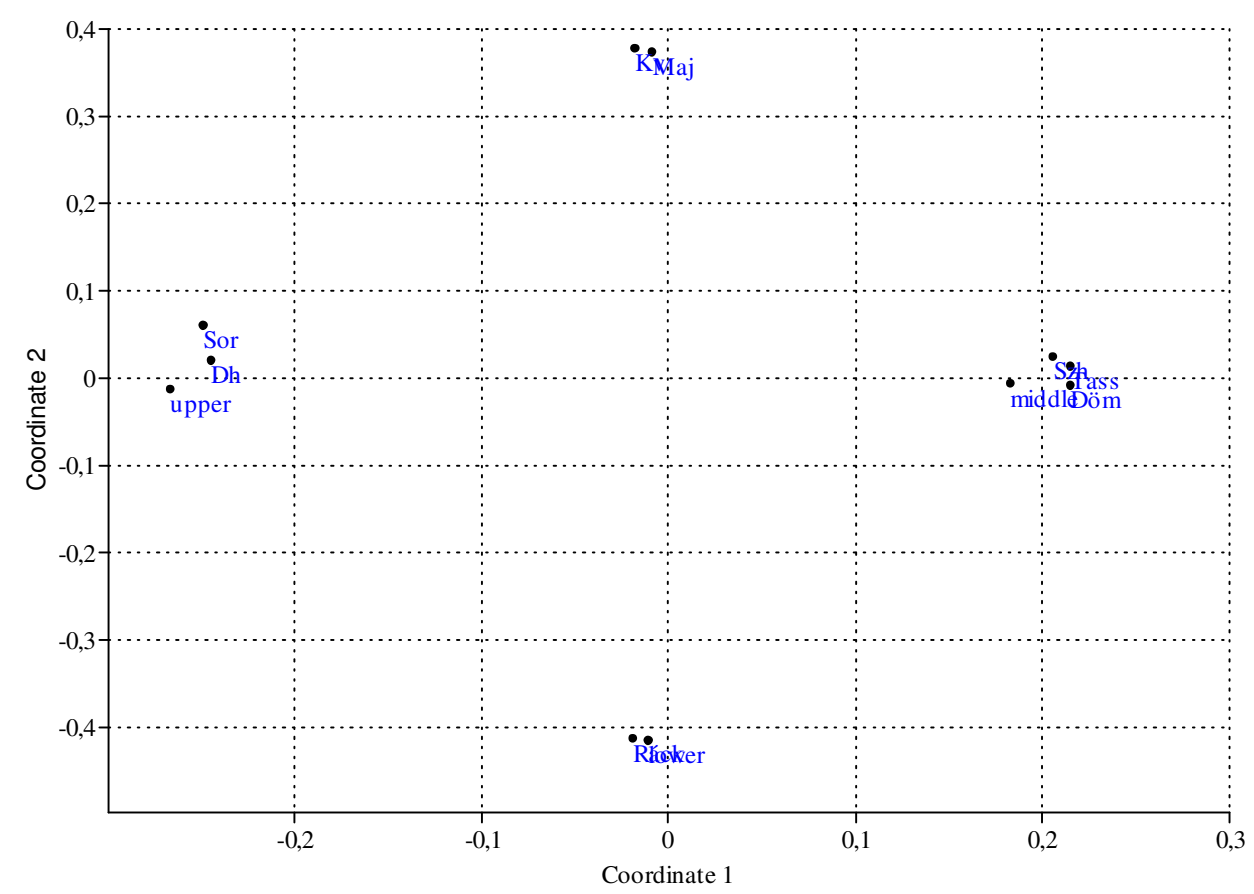

Figure 7. The NMDS ordination of the sampling sites (Euclidean distance).

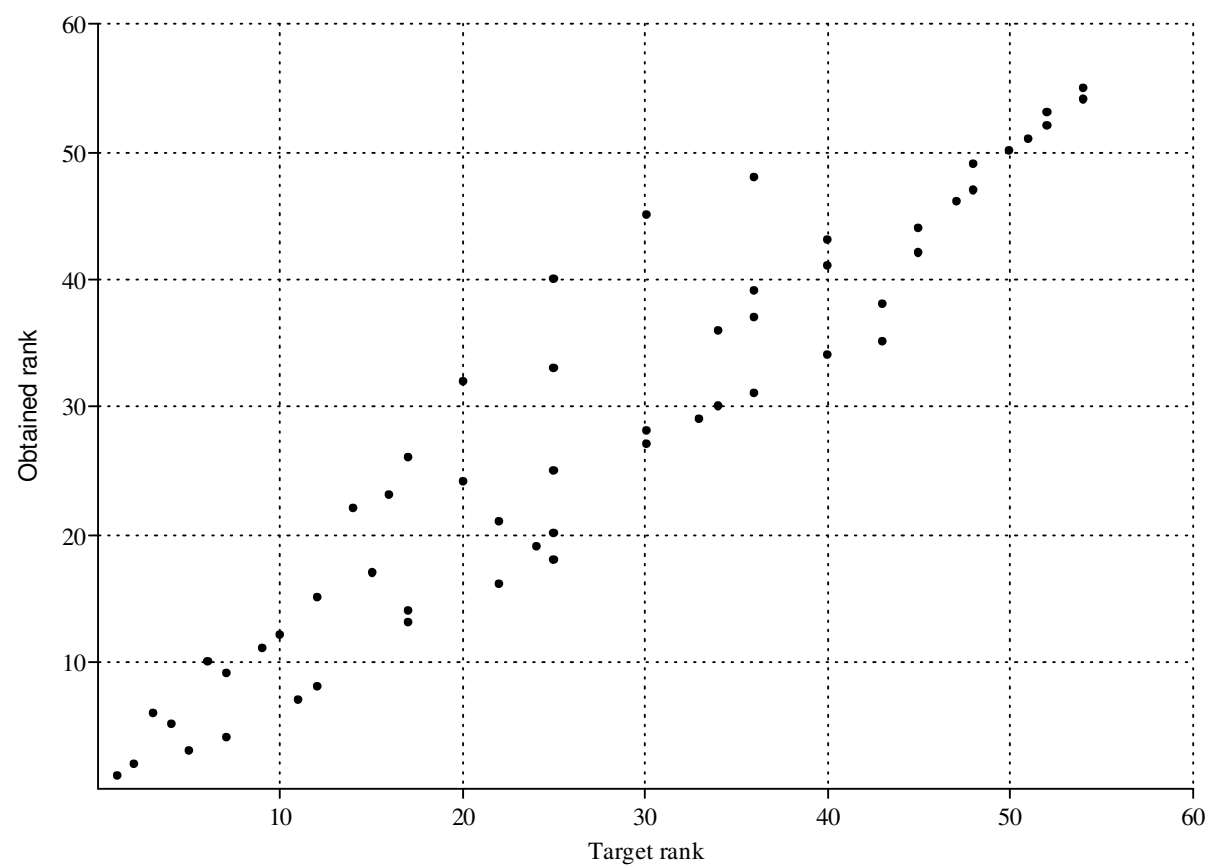

Figure 8. Shepard plot of the NMDS ordination of the sampling sites (Stress: 0,1624). 


\section{Similarity patterns of crustacean assemblages in different Hungarian water bodies}

Altogether 9 water bodies (including also the RSD) were considered in order to compare their Copepoda and Cladocera fauna in special consideration of the RSD. These 9 water bodies are separable based on the copepod and cladoceran fauna. According to the cluster analysis (Fig. 9) the RSD takes up a place closer to the stagnant waters (Lake Balaton, Lake Velence, Lake Fertö). The Rába and the Dráva are separated, whereas the Danube and the river Tisza form one goup. The Danube represents one cluster in spite of the fact that the Szigetköz region has its own features with some rare species not occurring in the main arm. The results of the cluster analysis is supported by the outcome of non-metric multidimensional scaling. It seems that the „large rivers” (Danube, Tisza), „small rivers” (Rába, Dráva) just as the main lakes (Lake Balaton, Lake Velence, Lake Fertö) can be separated based on the crustacean fauna.

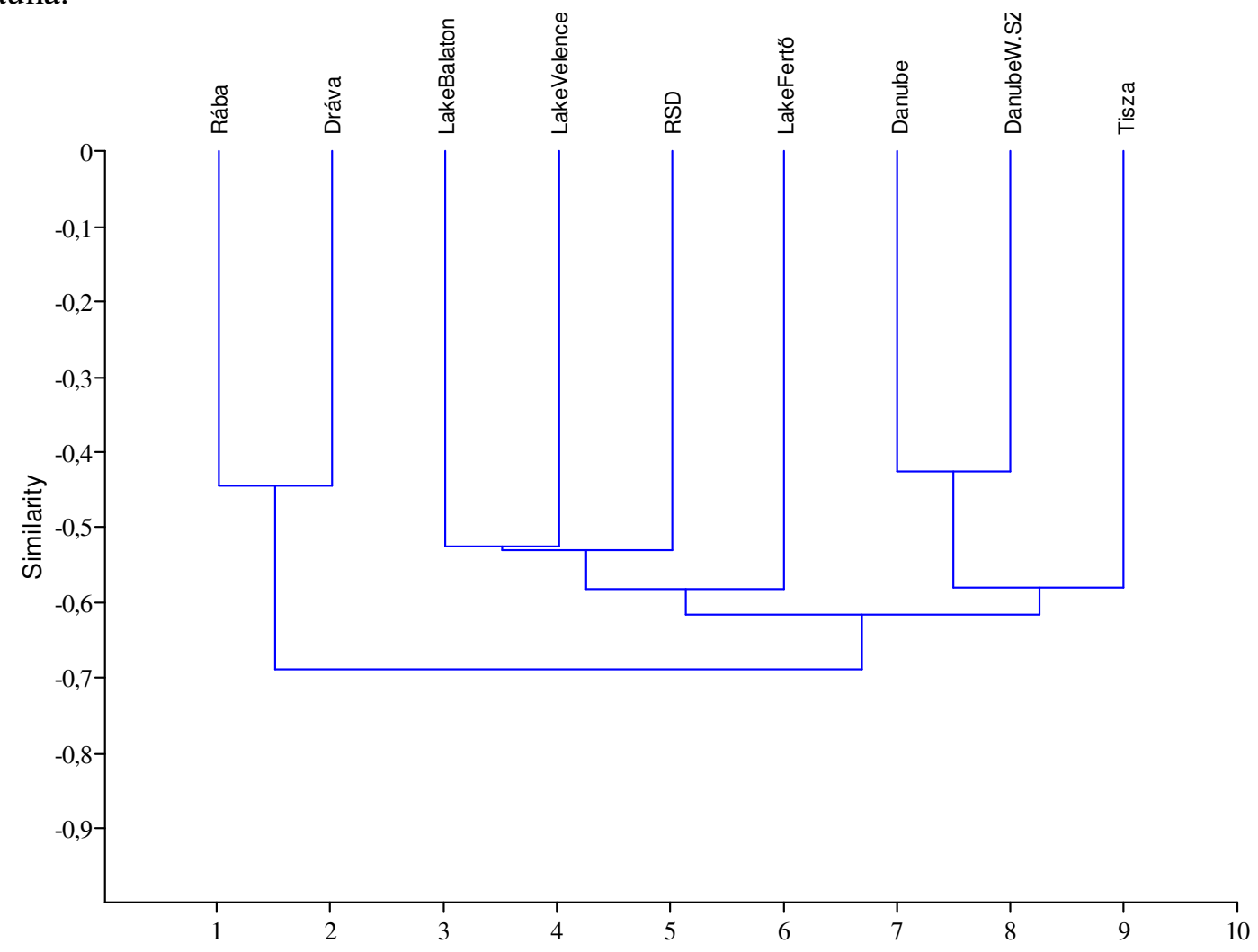

Figure 9. Similarity patterns of the examined water bodies based on the zooplankton (Copepoda, Cladocera) fauna (Euclidean distance).

According to our database some groups are worthwhile to distinguish in order to get a better view of the waters in consideration. The first group is formed by the species detected only in the river Danube (some of them are living in the RSD as well): Eurytemora velox, Cyclops furcifer, Megacyclops gigas, Simocephalus serrulatus, Holopedium gibberum, Bosmina longispina, Kurzia latissima, Chydorus gibbus, Daphnia similis, D. obtusa, D. parvula, Rhynchotalona falcata, Alona rustica, A. intermedia. From the above-mentioned species Daphnia obtusa, D. similis, Simocephalus serrulatus and Cyclops furcifer are mainly the inhabitants of small 
waters. Eurytemora velox deserves attention as this copepod was first observed in Hungary in the year 1991 in the Szigetköz region. It is an euryhaline species, prefers the shoreline vegetation, and gets rarely into the zooplankton samples in the open water. The second group consists of the species of the large rivers, the following species were recorded only from the river Danube and Tisza: Eudiaptomus graciloides, E. zachariasi, Diacyclops languidus, Metacyclops gracilis, Daphnia atkinsoni, which from only Eudiaptomus graciloides can be regarded as euplanktonic. Crustacean species exclusively living in our great lakes (Lake Balaton, Lake Velence, Lake Fertö) and in the RSD are Arctodiaptomus bacillifer, Diacyclops nanus, Diaphanosoma lacustris, D. mongolianum, Latona setifera, Daphnia cristata, Alona protzi, Anchistropus emarginatus (we should note that not each of the listed organisms is living in every water in the group). The above-mentioned organisms are chiefly characteristic of stagnant waters, while Arctodiaptomus bacillifer prefers sodic waters. It should be noted that the following species have not been found in the Hungarian section of the Danube: Diaphanosoma mongolianum, Ceriodaphnia rotunda, Metacyclops minutus, Mixodiaptomus kupelwieseri, Streblocerus serricaudatus. These are rare species excluding Ceriodaphnia rotunda. Species that have been reported in all water bodies in question are the following: Chydorus sphaericus, Bosmina longirostris, Daphnia longispina, Ceriodaphnia quadrangula, Scapholeberis mucronata, Alona rectangula, Megacyclops viridis, Acanthocyclops vernalis, A. robustus. These organisms are frequent species and can be found in a large variety of waters without exception. (According to our investigations in the RSD Bosmina longirostris, Acanthocyclops robustus and Alona rectangula are dominant). Frequently occurring species are as well: Cyclops strenuus, Paracyclops fimbriatus, Eucyclops serrulatus, Diacyclops bicuspidatus, Sida crystallina, Eurycercus lamellatus, Ceriodaphnia laticaudata, Macrothrix laticornis, M. hirsuticornis, Acroperus harpae, Simocephalus expinosus. Although these taxa are not rare they have not been observed in the Rába and Dráva, nevertheless they may be living there. The last group is composed of the species that have been found in all water bodies in the study with the exception of one water: Simocephalus vetulus, Pleuroxus aduncus, Alona quadrangularis, Macrocyclops albidus, Mesocyclops leuckarti, Thermocyclops crassus, Cyclops strenuus, Eucyclops serrulatus. The absence of these taxa does not mean definitely that they are not existing in the water in question, rather further investigations are needed to explore them. The species and their occurrence are presented in the Appendix.

The listed groups do not ephasize the characteristic species, rather focus on the specific, rare species of the particular water bodies. To illustrate this point take e. g. Eudiaptomus gracilis, which is characteristic of Lake Balaton but is not mentioned by the stagnant waters because it is existing in many water bodies.

Although Harpacticoida copepods are not included in the study we feel it necessary to add some pieces of information about this suborder neglected unfairly. According to Ponyi [34] the figures are the following: Lake Balaton (9 species), Lake Ferto (2 species), the Danube (4 species), the Tisza (6 species). In the RSD 2 species of Harpacticoida were observed: Attheyella trispinosa (Brady, 1880), Canthocamptus staphylinus (Jurine, 1820) [2, 19]. Their small size, complicated identification and collection make it hard to investigate these copepods [34]. 


\section{Discussion}

\section{Spatio-temporal changes}

According to the statistical results there are differences between the sections and decades based on the zooplankton fauna, that is the fauna of the upper section is similar to the fauna of our days and recent past, whereas the lower section shows greater similarity to the 50-70s. One reason for this phenomenon may be that most species occur at the lower section and in the 50-70s more species were detected in the water, whereas numerous taxa were found only in that time at the lower section. Consequently the above-mentioned isolation of the lower section seems to be supported by statistics. To summarize the results we can appoint that greater difference is existing between the two temporal intervals respectively between the sections (spatial intervals), than between the spatio-temporal changes simultaneously based on the zooplankton community. It means that both spatial and temporal changes in the zooplankton assemblage are worthwhile considering.

If we take the settlements into consideration we can see a triple grouping, namely the main sampling sites form groups according to the sections. This phenomenon supports that the three sections are meaningful to distinguish. However some deviations must be kept in mind. One possible reason for this can be the sampling error, that is on the one hand the sampling in the field (catching efficiency), on the other hand the data from literature may not be satisfactory enough to make perfect statements and more researches are needed. However if we are aware of this fact, we can make watchful conclusions from the evaluation of the data and this is the goal of the present study.

If we are interested in the spatial changes, it is worth mentioning that in the Danube a longitudinal pattern stands out, namely increasing abundance- and species number can be observed downwards $[11,12,15]$, whereas in the river Tisza several sections are distinguished based on the zooplankton composition [16]. These phenomena are similar to the spatial patterns of the zooplankton assemblages observed in the RSD.

\section{Similarity patterns}

The stagnant water character of the RSD has manifested in the results. Most of all the lower section can be regarded as a stagnant water, nevertheless most species live here (from the 66 species living in the RSD 61 were recorded in the lower section), so it contributes to the results. The clusters are mainly due to the influence of the rare species, as the characteristic species are often common species living in many types of water bodies, so they are not able to distinguish the examined waters at all times. To illustrate this point, we present some basic information of the characteristic crustacaen communities in the examined waters. The characteristic species of the RSD are Sida crystallina, Eurycercus lamellatus, Alona affinis, Pleuroxus truncatus, P. aduncus, Chydorus sphaericus, Bosmina longirostris, Macrocyclops albidus, Eucyclops serrulatus, Acanthocyclops vernalis, Megacyclops viridis, Mesocyclops leckarti [19]. According to Bothár [3] Eucyclops serrulatus, Acanthocyclops vernalis, A. robustus, Mesocyclops leuckarti, Thermocyclops crassus and Bosmina longirostris were dominant, while Bothár and Kiss [4] found Eucyclops serrulatus and Bosmina longirostris to be abundant. Our investigations show the dominance of Eucyclops serrulatus, Acanthocyclops robustus, Bosmina longirostris, Alona rectangula, Thermocyclops crassus. 
Frequent species in the river Danube are Bosmina longirosris, Acanthocyclops robustus, Diacyclops bicuspidatus, Mesocyclops leuckarti, Thermocyclops crassus [11, 12, 13, 15], in the water bodies of Szigetköz Bosmina longirostris, Chydorus sphaericus, Acanthocyclops robustus, A. vernalis, Mesocyclops leuckarti, Thermocyclops oithonoides, Eucyclops serrulatus, Alona rectangula, Pleuroxus aduncus, P. truncatus, Disparalona rostrata, Scapholeberis mucronata, Sida crystallina, Diaphanosoma brachyurum, Alona quadrangularis, Daphnia longispina, Macrothrix laticornis are abundant [8, 9, 10, 23]. The most frequently occuring species are characteristic to the planktonic communities of eutrophic stagnant and slow-flowing rivers $[11,12,15]$. The zooplankton fauna of the Tisza is characterized by euplanktonic organisms, many of them are cosmopolitan, adaptable species, the endogenic plankton elements are Bosmina longirostris, Daphnia longispina, Diaphanosoma brachyurum, Eucyclops serrulatus, Eudiaptomus gracilis [16]. Daphnia cucullata, Alona spp., Moina micrura, Cyclops spp., Thermocyclops spp., Leptodora kindtii are also frequent [49]. Dominant species in the Rába are Bosmina longirostris, Alona rectangula, Alona quadrangularis, Disparalona rostrata, Chydorus sphaericus, Moina micrura, Acanthocyclops robustus, Mesocyclops leuckarti, indicating medium and slow flow velocities, with moderate nutrient contents $[9,10,16]$. Most of the crustacean species living in the Dráva are cosmopolitan, adaptable ones, also occuring in different waters in Hungary [26]. In Lake Balaton Eudiaptomus gracilis, Cyclops vicinus, Mesocyclops leuckarti, Diaphanosoma mongolianum, Daphnia cucullata, Bosmina longirostris [35, 39, 47, 48] are abundant. The dominant crustacean species of Lake Velence are Bosmina longirostris, Ceriodaphnia quadrangula, Daphnia longispina, Diaphanosoma mongolianum, Mesocyclops leuckarti, Thermocyclops crassus, Cyclops vicinus and Arctodiaptomus bacillifer [33, 40], whereas in Lake Fertö Diaphanosoma brachyurum, Bosmina longirostris, Acanthocyclops vernalis, Arctodiaptomus spinosus, Alona rectangula, Simocephalus vetulus, Chydorus spp. are frequent [37, 38].

Present analysis is based on the data of occurrence of altogether 126 species. This is the $80 \%$ of the Hungarian copepod and cladoceran fauna. In the RSD 65 from the above-mentioned species were observed. Actually it is 66 if we take Diaphanosoma brachyurum into consideration, so it is the $42 \%$ of the Hungarian fauna. The latter species was neglected in the analysis of similarity patterns because of its indefinite data of occurrence. Nevertheless its occurrence in the RSD is not questionable, so it is included in the evaluation of the spatio-temporal patterns. In the Hungarian section of the river Danube (without the water bodies of Szigetköz) 90 species were described, which from 60 were observed in the RSD as well, while 30 were only reported from the Danube and 4 exclusively from the RSD (Graeteriella unisetigera, Anchistropus emarginatus, Moina brachiata, Oxyurella tenuicaudis).

In the future more emphasis should be put on the research of the RSD, we should not neglect this side arm since it has a great importance in many aspects. More attention is needed in the case of the sampling methods in order to get valuable and comparable data for detecting long-term changes. Moreover there is a demand on the continuous monitoring of water quality by indicator organisms even if the zooplankton is not included in the Water Framework Directive.

Acknowledgements. We wish to express our gratitude to Katalin Zsuga, Pál Gulyás, Anita Kiss and VITUKI Kht (Environmental and Water Research Institute). 


\section{REFERENCES}

[1] Abrantes, N., Goncalves, F. (2003): The dynamics of Ceriodaphnia pulchella (Cladocera) in laboratory. - Acta Oecologica 24: 245-249.

[2] Berinkey, L., Farkas, H. (1956): Haltáplálék vizsgálatok a Soroksári-Dunaágban. Állattani Közlemények 45: 45-58.

[3] Bothár, A. (1973): Crustacea-Planktonuntersuchungen im Donauarm von Soroksár. Annales Universitas Scientiarum Budapestinensis de Rolando Eötvös Nominatae (Danubialia Hungarica LXV.) 129-144.

[4] Bothár, A., Kiss, K. T. (1984): Phyto-und zooplankton Untersuchungen im Donauarm Ráckeve. -24. Arbeitstagung der IAD. Szentendre. Ungarn. II. 85-88.

[5] Einsle, U. (1993): Crustacea, Copepoda: Calanoida und Cyclopoida. -In: Schwoerbel, J \& P. Zwick (Eds): Süsswasserfauna von Mitteleuropa, Bd. 8, Heft 4, Teil 1, Gustav Fischer Verlag, Stuttgart: 1-208.

[6] Flössner, D. (1972): Krebstiere, Crustacea, Kiemen- und Blattfüsser, Branchiopoda, Fischlause, Branchiura. -In: Dahl, M., Peus, F. (ed.) Die Tierwelt Deutschlands, Gustav Fischer Verlag Jena.

[7] Forró, L., Gulyás, P. (1992): Eurytemora velox (Lilljeborg, 1853) (Copepoda, Calanoida) in the Szigetköz region of the Danube. -Miscellanea Zoologica Hungarica 7: 53-58.

[8] Gulyás, P. (1987): Tagliche Zooplankton-Untersuchungen im Donau-Nebenarm bei Ásványráró im Sommer 1985. -26. Arbeitstagung der IAD, Passau/Deutschland, 1987, Wissenschaftliche Kurzreferate 123-126.

[9] Gulyás, P. (1989): Rotatoria és Crustacea vizsgálatok a Szigetköz víztereiben. -Mühely 3: 1-10. Környezetminősító és Számítástechnikai Osztály tanulmánysorozata, MTA Földrajztudományi Kutató Intézet, Budapest.

[10] Gulyás, P. (1994): Studies on Rotatoria and Crustacea in the various water-Bodies of Szigetköz. -In: Kinzelbach (ed.) Biologie der Donau (Limnologie Aktuell, Band 2.), Gustav Fischer Verlag, Stuttgart.

[11] Gulyás, P. (1994): Studies on the rotatorian and crustacean plankton in the Hungarian section of the Danube between 1848,4 and 1659,0 riv. km. -In: Kinzelbach (ed.) Biologie der Donau (Limnologie Aktuell, Band 2.), Gustav Fischer Verlag, Stuttgart.

[12] Gulyás, P. (1995): Rotatoria and Crustacea plankton of the River Danube between Bratislava and Budapest. -Miscellanea Zoologica Hungarica 10: 7-19.

[13] Gulyás, P. (1997): Untersuchungen des Rotatoria- und Crustacea-Planktons an der Donaustrecke unterhalb Budapest sowie im Donauarm Ráckevei-Soroksári Duna (RSD). -32. Konferenz der IAD, Wien-Österreich 1997. Wissenschaftliche Referate 265-270.

[14] Gulyás, P. (1998): Szaprobiológiai indikátorfajok jegyzéke. -In: Vízi Természet- és Környezetvédelem, 6. kötet, Környezetgazdálkodási Intézet: 1-95.

[15] Gulyás, P. (2002): A Rotatoria és Crustacea plankton minőségi és mennyiségi vizsgálata a Dunán. -Vízügyi Közlemények 84: 601-620.

[16] Gulyás, P., Bancsi, I., Zsuga, K. (1995): Rotatoria and Crustacea fauna of the Hungarian watercourses. -Miscellanea Zoologica Hungarica 10: 21-47.

[17] Gulyás, P., Forró, L. (1999): Az ágascsápú rákok (Cladocera) kishatározója, 2. bővített kiadás. -In: Vízi Természet- és Környezetvédelem, 9. kötet, Környezetgazdálkodási Intézet: 1-237.

[18] Gulyás, P., Forró, L. (2001): Az evezőlábú rákok (Calanoida és Cyclopoida) alrendjeinek kishatározója, 2. bővített kiadás. -In: Vízi Természet- és Környezetvédelem, 14. kötet, Környezetgazdálkodási Intézet: 1-198.

[19] Gulyás, P., Thyahun, Sz. (1974): Adatok a Ráckevei Duna-ág kisrák faunájához. Hidrológiai Közlöny 54: 240-245.

[20] Győrbíró, T. (1974): A Ráckevei-Soroksári Duna halgazdálkodása. -Diplomadolgozat. 
[21] Just, I., Schöll, F., Tittizer, T. (ed.) (1998): Versuch einer Harmonisierung nationaler Methoden zur Bewertung der Gewassergüte im Donauarm am Beispiel der Abwasser der Stadt Budapest. - Umweltbundesamt, Berlin.

[22] Kiefer, F., Fryer, G. (1978): Das Zooplankton der Binnengewasser, 2. Teil, Band 26. -In: Elster, H. J., Ohle, W. (ed.) Die Binnengewasser, Stuttgart.

[23] Kiss, A. (2004): Long-term changes of Crustacean (Cladocera, Ostracoda, Copepoda) assemblages in Szigetköz Floodplain Area (Hungary) 1991-2002. -Internat. Assoc. Danube Res. 35: 2-7. Novi Sad.

[24] Korovchinsky, N. M. (1992): Sididae and Holopedidae (Crustacea: Daphniiformes). -In: Dumont, H. J. F. (ed.) Guides to the identification of the microinvertebrates of the continental waters of the world, SPB Academic Publishing, The Hague.

[25] Kovács, J. Gy. (1973): Fővárosunk tava a ráckevei (soroksári) Duna. -Vízgazdálkodás 13: 215-220.

[26] Körmendi, S., Lanszki, J. (2002): A Duna-Dráva Nemzeti Park különböző vizes élőhelyeinek zooplankton vizsgálata II. A Crustacea (Cladocera, Copepoda) fauna kvalitatív vizsgálata. -Somogyi Múzeumok Közleményei 15: 113-121.

[27] Litheráthy, P., Koller-Kreimer, V., Liska, I. (2002): Joint Danube Survey. Technical Report of the International Commission for the Protection of the Danube River. International Commission for the Protection of the Danube River, Vienna International Centre.

[28] Marosi, S., Somogyi, S. (ed.) (1990): Magyarország kistájainak katasztere. -MTA Földrajztudomány Kutató Intézet, Budapest, vol. I, pp. 38-43.

[29] Megyeri, J. (1971): A Tisza mezozooplanktonja. II. Entomostraca. -Szegedi Tanárk. Föisk. Tud. Közl. 10: 99-110.

[30] Mészáros, G., Vadadi-Fülöp, Cs., Udvari, Zs., Hufnagel, L. (2007): Analysis of spatial and temporal changes of the zooplankton fauna in the Ráckeve-Soroksár Danube arm. Tájökológiai Lapok (in press).

[31] Nedelkovics, A., Zsuga, K. (2006): Áttekintés a Tisza zooplankton-kutatásának eredményeiről (1955-2004). -Hidrológiai Közlöny 86: 54-55.

[32] Ponyi, J. (1997): A Balaton Cladocera és Copepoda rákjai. -Állattani Közlemények 82: 69-80.

[33] Ponyi, J. (1999): A Velencei-tó meiobentosz faunájának vizsgálata 1998-ban. Hidrológiai Tájékoztató 39: 26-28.

[34] Ponyi, J. (2001): Evezőlábú rákok (Copepoda) kevéssé ismert fajainak előfordulása Magyarországon. -Hidrológiai Tájékoztató 41:31-34.

[35] Ponyi, J. (2002): Nyíltvízi planktonrák-együttesek időbeli változása (1989-97 között) a Balatonban. -Hidrológiai Tájékoztató 42: 24-26.

[36] Ponyi, J. (2002): A Balaton rákfaunája (Crustacea) és változásai az elmúlt 100 évben. Állattani Közlemények 87: 179-189.

[37] Ponyi, J., Dévai, I. (1977): A Fertő magyar területének rákjai (Crustacea). -Hidrológiai Közlöny 57: 262-270.

[38] Ponyi, J., Dévai, I. (1979): The Crustacea of the Hungarian area of Lake Fertö. -Opuscula Zoologica Budapest 16: 107-127.

[39] Ponyi, J., Péter, I., Zánkai, N. (1982): Az Eudiaptomus gracilis (G. O. Sars) (Copepoda, Calanoida) populációja szerkezetének és produkciójának naponkénti változása nyáron, a Balatonban. -Hidrológiai Közlöny 62: 260-266.

[40] Reskóné, M., Ponyi, J., Szító, A. (1999): A zooplankton, a meio- és a makrozoobentosz mennyisége, faji összetétele a Velencei-tóban. -Hidrológiai Közlöny 79: 369-371.

[41] Rylov, W. M. (1935): Das Zooplankton der Binnengewasser, Band 15. -In: Thienemann, A. (ed.) Die Binnengewasser, Stuttgart.

[42] Schiefner, K., Urbányi, A. (1970): A Soroksári Duna-ág komplex higiénés vizsgálata. Hidrológiai Közlöny 50: 318-324. 
[43] Smirnov, N. N. (1996): Cladocera: the Chydorinae and Sayciinae (Chydoridae) of the world. -In: Dumont, H. J. F. (ed.) Guides to the identification of the microinvertebrates of the continental waters of the world, SPB Academic Publishing, The Hague.

[44] Thyahun, Sz. (1977): Populatiodynamische Untersuchungen der Mesofauna in den Laichkrautbestanden des Donauarms von Soroksár. -Opuscula Zoologica Budapest 13: 83-106.

[45] Vadadi-Fülöp, Cs., Mészáros, G. (2007): A Ráckevei-Soroksári Dunával kapcsolatos zooplankton és makrogerinctelen kutatások áttekintése. -Hidrológiai Közlöny 87: 60-63.

[46] Vadadi-Fülöp, Cs., Mészáros, G., Jablonszky, Gy., Hufnagel, L. (2007): Ecology of the Ráckeve-Soroksár Danube -a review. -Applied Ecology and Environmental Research 5 (1): 133-163.

[47] Zánkai, N. (1987): A rákplankton összetétele és sürüsége a Balaton nyílt vizében és partközelben. -Állattani Közlemények 74: 169-181.

[48] Zánkai, N., Ponyi, J. (1997): Nyíltvízi planktonrák-együttesek szerkezetének tér- és időbeli változása a Balaton két, trofitásban eltérő területén (Keszthelyi és Siófoki medence). -Állattani Közlemények 82: 87-108.

[49] Zsuga, K., Tóth, A., Pekli, J., Udvari, Zs. (2004): A Tisza vízgyüjtő zooplanktonjának alakulása az 1950-es évektől napjainkig. -Hidrológiai Közlöny 84: 175-178.

\section{APPENDIX}

\begin{tabular}{|c|c|c|c|c|c|c|c|c|c|}
\hline Taxa & RSD & Tisza & Danube & $\begin{array}{l}\text { Danube } \\
\text { e W.SZK }\end{array}$ & $\begin{array}{l}\text { Lake } \\
\text { Balaton }\end{array}$ & $\begin{array}{c}\text { Lake } \\
\text { Velence }\end{array}$ & $\begin{array}{l}\text { Lake } \\
\text { Fertó }\end{array}$ & Rába & Dráva \\
\hline $\begin{array}{l}\text { Oxyurella tenuicaudis (Sars, } \\
1862 \text { ) }\end{array}$ & + & + & + & & + & + & + & & \\
\hline $\begin{array}{l}\text { Alonella exigua (Lilljeborg, } \\
1853)\end{array}$ & + & + & + & + & + & & & & \\
\hline $\begin{array}{l}\text { Alonella nana (Baird, 1850) } \\
\text { Anchistropus emarginatus }\end{array}$ & + & + & + & + & & + & & & + \\
\hline $\begin{array}{c}\text { Sars, } 1862 \\
\text { Bosmina longirostris (O. F. }\end{array}$ & + & & & & + & & & & \\
\hline Müller, 1785) & + & + & + & + & + & + & + & + & + \\
\hline $\begin{array}{c}\text { Bosmina coregoni Baird, } 1857 \\
\text { Camptocercus rectirostris }\end{array}$ & + & & + & + & + & & & & \\
\hline $\begin{array}{c}\text { Schoedler, } 1862 \\
\text { Leptodora kindtii (Focke, } \\
\text { 1844) }\end{array}$ & + & + & + & + & + & + & & & + \\
\hline $\begin{array}{c}\text { Sida crystallina }(\mathrm{O} \text {. F. Müller, } \\
1776)\end{array}$ & + & + & + & + & + & + & + & & \\
\hline Daphnia cucullata Sars, 1862 & + & + & + & + & + & & & + & + \\
\hline $\begin{array}{c}\text { Daphnia hyalina Leydig, } 1860 \\
\text { Daphnia longispina O. F. }\end{array}$ & + & & + & + & + & + & & & \\
\hline $\begin{array}{c}\text { Müller, } 1785 \\
\text { Disparalona rostrata (Koch, }\end{array}$ & + & + & + & + & + & + & + & + & + \\
\hline $\begin{array}{l}\text { 1841) } \\
\text { Eurycercus lamellatus (O. F. }\end{array}$ & + & + & + & + & + & + & & + & \\
\hline $\begin{array}{c}\text { Müller, 1785) } \\
\text { Graptoleberis testudinaria }\end{array}$ & + & + & + & + & + & + & + & & \\
\hline $\begin{array}{l}\text { (Fischer, 1848) } \\
\text { Simocephalus serrulatus }\end{array}$ & + & & + & + & + & + & + & & \\
\hline $\begin{array}{l}\text { (Koch, 1841) } \\
\text { Simocephalus vetulus (O. F. }\end{array}$ & + & & + & + & & & & & \\
\hline Müller, 1776) & + & + & + & + & + & + & + & + & \\
\hline
\end{tabular}




\begin{tabular}{|c|c|c|c|c|c|c|c|c|c|}
\hline Taxa & RSD & Tisza & Danube & $\begin{array}{l}\text { Danube } \\
\text { W.SZK }\end{array}$ & $\begin{array}{c}\text { Lake } \\
\text { Balaton }\end{array}$ & $\begin{array}{c}\text { Lake } \\
\text { Velence }\end{array}$ & $\begin{array}{l}\text { Lake } \\
\text { Ferto" }\end{array}$ & Rába & Dráva \\
\hline $\begin{array}{c}\text { Moina macrocopa (Straus, } \\
1820)\end{array}$ & + & + & + & + & & & & & \\
\hline Moina micrura Kurz, 1874 & + & + & + & + & & + & + & + & + \\
\hline $\begin{array}{c}\text { Monospilus dispar Sars, } 1862 \\
\text { Ceriodaphnia quadrangula }\end{array}$ & + & & + & + & + & & & & \\
\hline $\begin{array}{l}\text { (O. F. Müller,1785) } \\
\text { Ceriodaphnia dubia Richard, }\end{array}$ & + & + & + & + & + & + & + & + & + \\
\hline $\begin{array}{c}1894 \\
\text { Ceriodaphnia laticaudata P. }\end{array}$ & + & & + & + & & + & & & \\
\hline $\begin{array}{c}\text { E. Müller, } 1867 \\
\text { Ceriodaphnia pulchella Sars, } \\
1862\end{array}$ & + & + & + & + & + & + & + & & \\
\hline $\begin{array}{c}\text { Scapholeberis mucronata (O. } \\
\text { F. Müller, 1785) }\end{array}$ & + & + & + & + & + & + & + & + & + \\
\hline $\begin{array}{c}\text { Macrothrix laticornis (Fischer, } \\
\text { 1848) }\end{array}$ & + & + & + & + & + & + & + & & \\
\hline $\begin{array}{c}\text { Macrothrix hirsuticornis } \\
\text { Norman \& Brady, } 1867\end{array}$ & + & + & + & + & + & + & + & & \\
\hline $\begin{array}{c}\text { Iliocryptus sordidus (Liévin, } \\
1848)\end{array}$ & + & & + & + & + & & + & + & \\
\hline $\begin{array}{c}\text { Iliocryptus agilis Kurz, } 1878 \\
\text { Acroperus harpae (Baird, }\end{array}$ & + & + & + & + & + & + & & & \\
\hline 1834$)$ & + & + & + & + & + & + & + & & \\
\hline $\begin{array}{c}\text { Pleuroxus truncatus (O. F. } \\
\text { Müller, 1785) }\end{array}$ & + & + & + & + & & & & & + \\
\hline $\begin{array}{c}\text { Leydigia leydigi (Schoedler, } \\
1863)\end{array}$ & + & + & + & + & + & + & & & \\
\hline $\begin{array}{c}\text { Chydorus sphaericus (O. F. } \\
\text { Müller, 1776) }\end{array}$ & + & + & + & + & + & + & + & + & + \\
\hline $\begin{array}{c}\text { Pleuroxus trigonellus (O. F. } \\
\text { Müller, 1785) }\end{array}$ & + & & + & + & + & + & + & & + \\
\hline $\begin{array}{l}\text { Pleuroxus uncinatus Baird, } \\
1850\end{array}$ & + & & + & + & + & & + & & \\
\hline $\begin{array}{l}\text { Pleuroxus aduncus (Jurine, } \\
1820 \text { ) }\end{array}$ & + & + & + & + & + & + & + & + & \\
\hline $\begin{array}{c}\text { Pseudochydorus globosus } \\
\text { (Baird, 1843) }\end{array}$ & + & + & + & + & + & & & & \\
\hline $\begin{array}{c}\text { Alona quadrangularis (O. F. } \\
\text { Müller, 1785) }\end{array}$ & + & & + & + & + & + & + & + & + \\
\hline Alona affinis (Leydig, 1860) & + & + & + & + & + & + & & & \\
\hline Alona intermedia Sars, 1862 & + & & + & + & & & & & \\
\hline Alona guttata Sars, 1862 & + & & + & + & + & + & + & & \\
\hline $\begin{array}{c}\text { Alona rectangula Sars, } 1862 \\
\text { Holopedium gibberum }\end{array}$ & + & + & + & + & + & + & + & + & + \\
\hline Zaddach, 1855 & & & + & + & & & & & \\
\hline Daphnia magna Straus, 1820 & & + & + & + & + & + & + & & \\
\hline Daphnia atkinsoni Baird, 1859 & & + & + & + & & & & & \\
\hline Daphnia similis Claus, 1876 & & & + & & & & & & \\
\hline $\begin{array}{c}\text { Daphnia obtusa Kurz, } 1874 \\
\text { Daphnia curvirostris Eylman, } \\
1887\end{array}$ & & & + & + & + & & + & & \\
\hline Daphnia pulex Leydig, 1860 & + & + & + & + & + & + & & + & \\
\hline
\end{tabular}




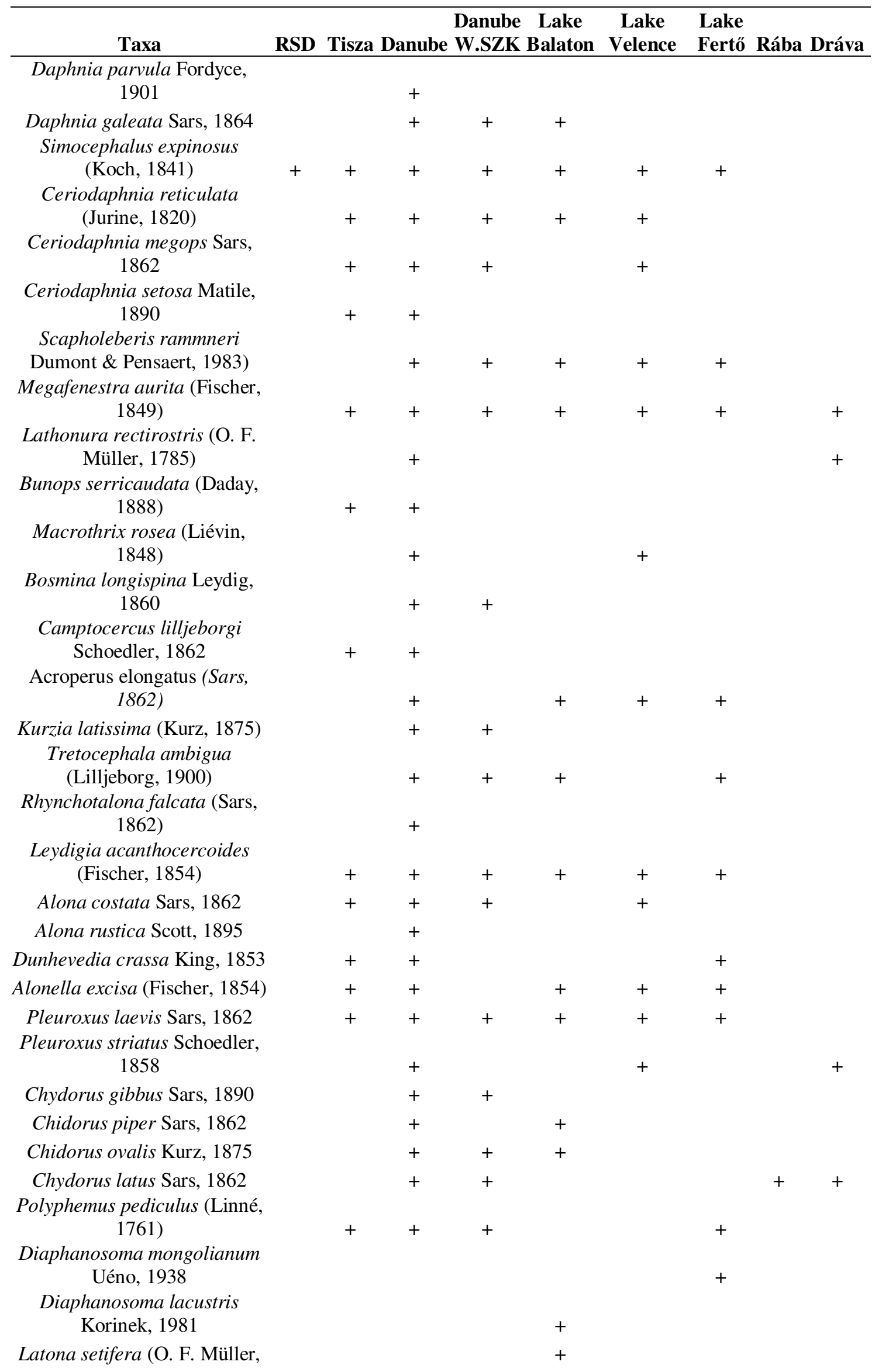




\begin{tabular}{|c|c|c|c|c|c|c|c|c|c|}
\hline Taxa & RSD & Tisza & Danube & $\begin{array}{l}\text { Danube } \\
\text { W.SZK }\end{array}$ & $\begin{array}{c}\text { Lake } \\
\text { Balaton } \\
\end{array}$ & $\begin{array}{c}\text { Lake } \\
\text { Velence } \\
\end{array}$ & $\begin{array}{l}\text { Lake } \\
\text { Fertó }\end{array}$ & Rába & Dráva \\
\hline 1875) & & & & & & & & & \\
\hline Daphnia cristata Sars, 1862 & & & & & + & & & & \\
\hline $\begin{array}{c}\text { Moina brachiata (Jurine, } \\
\text { 1820) }\end{array}$ & + & + & + & & + & + & + & & \\
\hline $\begin{array}{c}\text { Ceriodaphnia rotunda Sars, } \\
1862\end{array}$ & & & & & + & + & + & & + \\
\hline $\begin{array}{l}\text { Streblocerus serricaudatus } \\
\text { (Fischer, 1849) }\end{array}$ & & & & & & + & & & \\
\hline Alona protzi Hartwig, 1900 & & & & & + & & & & \\
\hline $\begin{array}{c}\text { Graeteriella unisetigera } \\
\text { (Graeter, 1908) }\end{array}$ & + & & & & & & & & \\
\hline $\begin{array}{c}\text { Macrocyclops albidus (Jurine, } \\
1820 \text { ) }\end{array}$ & + & + & + & + & + & + & + & & + \\
\hline $\begin{array}{c}\text { Macrocyclops fuscus (Jurine, } \\
1820 \text { ) }\end{array}$ & + & + & + & + & & + & + & & + \\
\hline $\begin{array}{c}\text { Eucyclops serrulatus (Fischer, } \\
1851 \text { ) }\end{array}$ & + & + & + & + & + & + & + & & + \\
\hline $\begin{array}{l}\text { Eucyclops macruroides } \\
\text { (Lilljeborg, 1901) }\end{array}$ & + & + & + & + & + & + & & & \\
\hline $\begin{array}{c}\text { Eucyclops macrurus (Sars, } \\
1863 \text { ) }\end{array}$ & + & & + & + & + & + & & & \\
\hline $\begin{array}{l}\text { Paracyclops fimbriatus } \\
\text { (Fischer, 1853) }\end{array}$ & + & + & + & + & + & + & + & & \\
\hline $\begin{array}{c}\text { Cyclops strenuus Fischer, } \\
1851\end{array}$ & + & + & + & + & + & + & + & & + \\
\hline $\begin{array}{l}\text { Cyclops vicinus Uljanin, } 1875 \\
\text { Megacyclops viridis (Jurine, }\end{array}$ & + & + & + & + & + & + & & & + \\
\hline $\begin{array}{c}1820) \\
\text { Acanthocyclops vernalis }\end{array}$ & + & + & + & + & + & + & + & + & + \\
\hline $\begin{array}{c}\text { (Fischer, 1853) } \\
\text { Acanthocyclops robustus }\end{array}$ & + & + & + & + & + & + & + & + & + \\
\hline $\begin{array}{c}\text { (Sars, 1863) } \\
\text { Diacyclops bicuspidatus }\end{array}$ & + & + & + & + & + & + & + & + & + \\
\hline (Claus, 1857) & + & + & + & + & + & + & + & & \\
\hline $\begin{array}{c}\text { Cryptocyclops bicolor Sars, } \\
1927\end{array}$ & + & + & + & + & + & & + & & + \\
\hline $\begin{array}{c}\text { Mesocyclops leuckarti (Claus, } \\
1857 \text { ) }\end{array}$ & + & + & + & + & + & + & + & & + \\
\hline $\begin{array}{l}\text { Thermocyclops crassus } \\
\text { (Fischer, 1853) }\end{array}$ & + & + & + & + & + & + & + & & + \\
\hline $\begin{array}{c}\text { Thermocyclops oithonoides } \\
\text { (Sars, 1863) }\end{array}$ & + & + & + & + & & & & & \\
\hline $\begin{array}{c}\text { Eudiaptomus gracilis (Sars, } \\
1863 \text { ) }\end{array}$ & + & + & + & + & + & + & & & + \\
\hline $\begin{array}{c}\text { Eurytemora velox (Lilljeborg, } \\
1853)\end{array}$ & + & & + & & & & & & \\
\hline $\begin{array}{c}\text { Ectocyclops phaleratus (Koch, } \\
1838)\end{array}$ & + & + & + & + & + & + & & & \\
\hline $\begin{array}{c}\text { Diaptomus castor (Jurine, } \\
1820 \text { ) }\end{array}$ & & & + & & + & & & & \\
\hline $\begin{array}{l}\text { Eudiaptomus vulgaris } \\
\quad \text { (Schmeil, 1896) }\end{array}$ & & & + & + & & & + & & \\
\hline Eudiaptomus graciloides & & + & + & + & & & & & \\
\hline
\end{tabular}




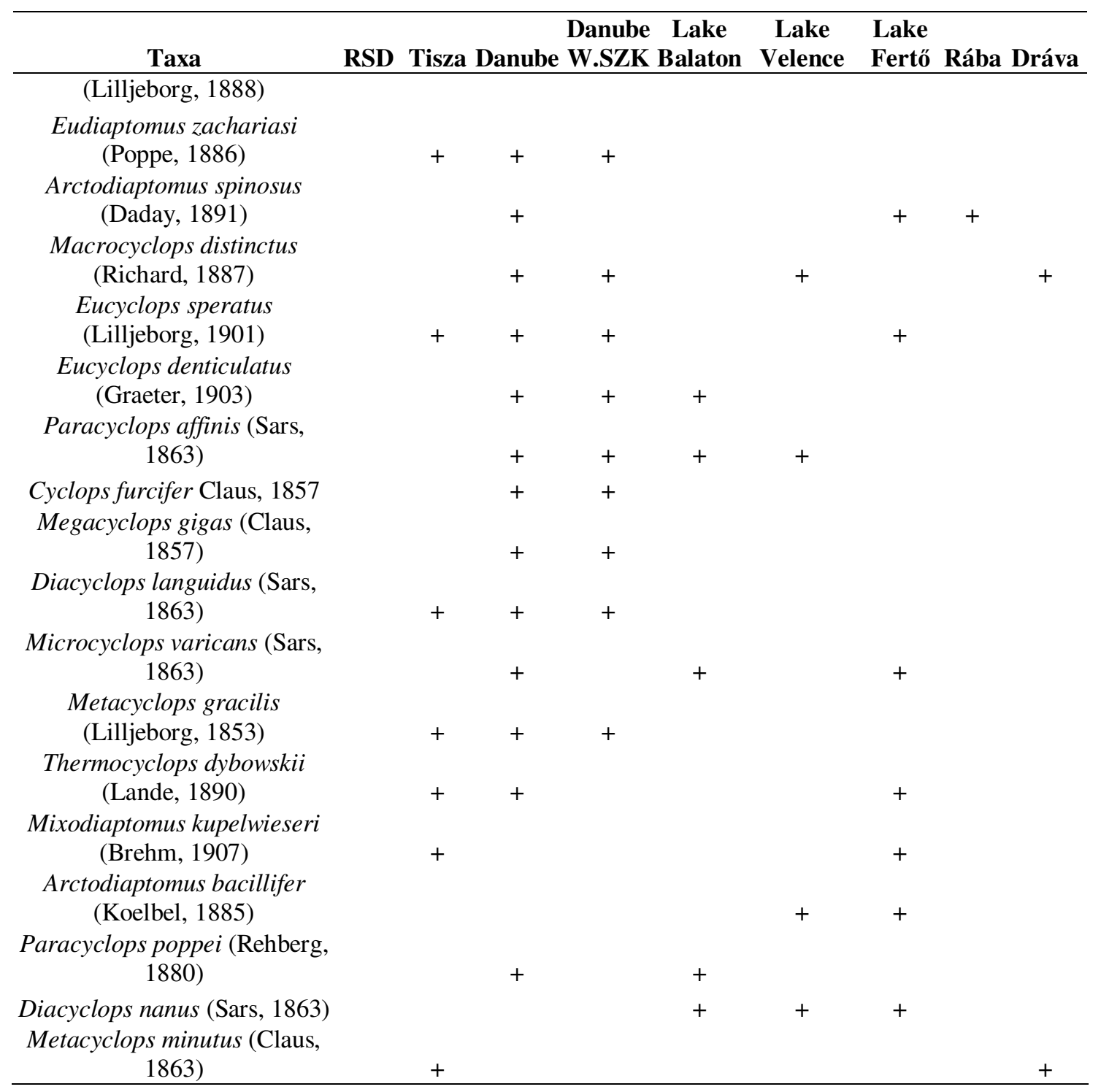

